\title{
Stop and Search, Terrorism and the Human Rights Deficit
}

\author{
Richard A. Edwards*
}

\begin{abstract}
This paper discusses the judgment of the House of Lords in Gillan [2006] UKHL 12, where the law lords examined the compatibility of the power in ss. 44 and 45 of the Terrorism Act 2000 to stop and search individuals with the Human Rights Act 1998. It is argued that the decision of the House of Lords that ss. 44 and 45 are compatible with Convention rights was wrong for a number of reasons. Not only did the House of Lords fail to interpret and apply the applicable Convention rights correctly, it also missed an important opportunity to develop the principle of legality in the context of the Human Rights Act. Moreover, the House failed to deal adequately with the troubling question of whether the exercise and use of the stop and search power under the Terrorism Act was racially discriminatory. These issues take on a particular importance not only because of the greater use of the power since the so-called ' $7 / 7$ attacks', but also because of the disparate impact that the use of the power has on racial minorities.
\end{abstract}

Keywords: human rights, stop and search, legality, discrimination, terrorism, permissive powers

\section{Introduction}

On 9 September 2003 Kevin Gillan, a PhD student at the University of Sheffield, was en route to a peaceful demonstration against the arms trade when he was stopped and searched by two Metropolitan police officers. Gillan was delayed for 20 minutes while the officers exercised their powers under ss. 44 and 45 of the Terrorism Act 2000 (TA) ${ }^{1}$ to search for 'articles connected with terrorism'. ${ }^{2}$ The search yielded nothing incriminating and no arrest was made. Gillan subsequently brought an action by way of judicial review against the Metropolitan

* Department of Law, UWE Bristol. My thanks to Ed Cape, Howard Davis and the anonymous referee for their very helpful comments on this paper. The usual disclaimer applies.

1 Hereafter the Terrorism Act 2000 (c.11) is referred to as the 'TA' and ss. 44-45 of the Terrorism Act as 'ss. 44-45'.

2 44. (2) An authorization under this subsection authorizes any constable in uniform to stop a pedestrian in an area or at a place specified in the authorization and to search-

(a) the pedestrian;

(b) anything carried by him. 
Police Service contending, amongst other things, that the stop and search power contained in Part V of the TA was incompatible with his Convention rights as scheduled to the Human Rights Act 1998 (HRA). ${ }^{3}$

\section{An Exceptional Police Power:- the Background}

Sections 44 and 45 were enacted in 2000 by Parliament as part of the counterterrorist powers in Part V of the TA. The TA is primarily a consolidating measure intended to provide the UK with a permanent legal regime for dealing with terrorism. These permanent powers combine many of the previous statutory provisions passed as temporary, emergency provisions. But once again powers that were once viewed as exceptional and temporary have become permanent and unexceptional. ${ }^{4}$ A legal regime designed to be a temporary derogation

(3) An authorization under subsection (1) or (2) may be given only if the person giving it considers it expedient for the prevention of acts of terrorism.

(5) If an authorization is given orally, the person giving it shall confirm it in writing as soon as is reasonably practicable.

45. (1) The power conferred by an authorisation under section 44(1) or (2)(a) may be exercised only for the purpose of searching for articles of a kind which could be used in connection with terrorism, and

(b) may be exercised whether or not the constable has grounds for suspecting the presence of articles of that kind.

(2) A constable may seize and retain an article which he discovers in the course of a search by virtue of section 44(1) or (2) and which he reasonably suspects is intended to be used in connection with terrorism.

(3) A constable exercising the power conferred by an authorization may not require a person to remove any clothing in public except for headgear, footwear, an outer coat, a jacket or gloves.

(4) Where a constable proposes to search a person or vehicle by virtue of section 44(1) or (2) he may detain the person or vehicle for such time as is reasonably required to permit the search to be carried out at or near the place where the person or vehicle is stopped.

47. (1) A person commits an offence if he-

(a) fails to stop a vehicle when required to do so by a constable in the exercise of the power conferred by an authorization under section 44(1);

(b) fails to stop when required to do so by a constable in the exercise of the power conferred by an authorization under section 44(2);

(c) wilfully obstructs a constable in the exercise of the power conferred by an authorization under section 44(1) or (2).

(2) A person guilty of an offence under this section shall be liable on summary conviction to-

(a) imprisonment for a term not exceeding six months,

(b) a fine not exceeding level 5 on the standard scale, or

(c) both.

3 Human Rights Act 1998 (c.42), s. 1 and Sch 1. Hereinafter HRA.

4 Such emergency laws in the United Kingdom follow a familiar if somewhat depressing path to permanence. To begin with statutory regimes such as the Prevention of Terrorism (Temporary Provisions) Act 1989, c. 4 were viewed as regrettable if necessary departures from the normal criminal justice process. Exceptional violence requires an exceptional response. But with the passage of time Parliament has in most cases come to the view that these once temporary 
and developed to deal with a specific threat has been replaced by a permanent regime and intended to counter general threats. Indeed, the radiating effect of emergency laws has in modern times contaminated other parts of the criminal justice process.

The powers contained in Part V of the TA have their origins in the Criminal Justice and Public Order Act 1994 (CJPOA). Before the passage of the 1994 Act the police would have to rely on s. 1 of the Police and Criminal Evidence Act 1984 (PACE) to stop and search individuals suspected of being involved in terrorist activities. From the police perspective s. 1 of PACE suffered from the handicap of requiring a reasonable suspicion. ${ }^{5}$ The CJPOA changed this situation by amending the Prevention of Terrorism (Temporary Provisions) Act (PTA) 1989 to include a standardless power to stop both vehicles and people. In other words the power is not constrained by any conditions precedent that need to be satisfied before it can be lawfully exercised. ${ }^{6}$ By way of contrast, an ordinary stop and search under PACE requires that a police constable has 'reasonable grounds for suspecting that he will find stolen or prohibited articles' ${ }^{7}$ Under the PTA a police officer can stop an individual and search him for 'articles of a kind which could be used for a purpose connected with the commission, preparation or instigation of acts of terrorism' ${ }^{8}$ although not the actual person. The power was qualified through the requirements that it must have been both authorized by an appropriate officer and its exercise must be connected with terrorism relating to either Northern Ireland or the affairs of the UK. Unless renewed the power lapsed after 28 days. These powers were judged to be necessary by the then Home Secretary in order to deal with an anticipated upsurge in Irish Nationalist violence aimed at targets in London, which subsequently failed to materialize.

In 1996 Parliament extended the power to include the search of persons. ${ }^{9}$ The authorization process differed in two respects from the previous regime. First, the authorization could be given orally by the appropriate officer, although it would need to be confirmed later in

measures are essential bulwarks in the 'war against drugs/crime/terror'. The exception has once more become the norm. A good example of this tendency in action is of course the changes to the right to silence enacted first in the context of Northern Ireland, and subsequently in the rest of the UK.

5 In the alternative an officer might have decided to make an arrest under s. 14 of the Prevention of Terrorism Act (Additional Powers) Act 1996, c. 7.

6 The CJPOA itself contained a similar new power in s. 60 where an appropriate office can authorize standardless searches and seizures if he reasonably believes that incidents involving serious violence may take place in any locality in his area.

7 PACE, s. 1(3).

8 Prevention of Terrorism (Temporary Provisions) Act 1989 (c. 4), s. 13A, inserted by CJPOA, s. 81.

9 Prevention of Terrorism (Additional Powers) Act 1996 (c. 7), s. 5 inserting s.13B into the PTA 1989. Although a person could now be searched as opposed to anything they were carrying, s. 13B limited that power: 'Nothing in this section authorizes a constable to require a person to remove any of his clothing in public other than any headgear, footwear, outer coat, jacket or gloves' (s. 13B(4)). 
writing. And second, the Home Secretary was granted the power to superintend the authorizations. ${ }^{10}$ As with much emergency legislation before, $^{11}$ and since, ${ }^{12}$ the 1996 amendments and additions were rushed through Parliament with little effective debate, in this case in just one day. ${ }^{13}$ The new provisions were justified on the grounds that the government feared a terrorist attack during the 80th anniversary of the Dublin Rising. Of particular concern was the possibility of attacks by nationalists armed with pocket incendiary devices. It subsequently became apparent that the need for such provisions had been considered some time before. ${ }^{14}$

It was these temporary provisions that were re-enacted in the permanent TA, albeit with some amendments. ${ }^{15}$ As it now stands s. 44 empowers a senior police officer to authorize searches under s. 45 where he 'considers it expedient for the prevention of acts of terrorism'. ${ }^{16}$ An authorization may be made orally although it must be confirmed as soon as is reasonably practicable in writing. ${ }^{17}$ Moreover, every authorization made under s. 44 must be confirmed by the Home Secretary within 48 hours, or it will lapse. In any case, an authorization lapses after 28 days unless renewed. ${ }^{18}$ While authorized, a police officer may search vehicles and people for 'articles of a kind which could be used in connection with terrorism . . . whether or not the constable has grounds for suspecting the presence of articles of that kind'. ${ }^{19}$ The power is thus derived from the authorization. And because it represents a departure from the normal standard applicable to police searches the power has, albeit it to a limited extent, been surrounded by safeguards. ${ }^{20}$ First, the power needs to be authorized by the appropriate officer with knowledge of the area where it will be applied. That activation is subject to confirmation by the Home Secretary. And second, given the extraordinary nature of the power, the authorizations should last for a limited time. However, so that the police can rapidly respond to a threat should it suddenly arise, the relevant officer has the power to authorize searches orally. Indeed, it

10 See K. Reid 'Prevention of Terrorism (Additional Powers) Act 1996' [1996] 4 Web JCLI; see http://webjcli.ncl.ac.uk/1996/issue4/reid4.html.

11 Prevention of Terrorism Act 1974 passed in the wake of the Birmingham pub bombings. At the time the threat to the UK from Irish Republican violence was described as the greatest threat since the end of the Second World War. See e.g. Hansard HC Deb, vol 882, col 743 (28th November 1974).

12 Anti-Terrorism, Crime and Security Act 2001 (c. 24).

13 O. Gross, 'Chaos Rules: Should Responses to Violent Crises Always be Constitutional?' (2003) 112 Yale LJ 1011, 1033.

14 See above n. 10.

15 R(Gillan) v Commissioner of the Metropolitan Police [2006] UKHL 12 at para. 9, per Lord Bingham.

16 TA, ss. 44 and 45(3). The officer must be of ACPO rank: ss. 44 and 45(4).

17 Ibid., ss. 44 and 45(5).

18 Ibid., s. 46.

19 Ibid., ss. 44 and 45(1).

20 Whether or not they are effective will be considered below. For example, see the discussion in Part VI on legality and discrimination. 
might be argued the scheme in Part V seeks to balance the need for a special power against the broader interests of a free society by limiting the departure from the legal norm to situations where it is necessary. However, whatever the theory, since the Terrorism Act came into force there has been a substantial period where a series of 'rolling authorizations' has been in force in the Metropolitan and City of London police areas. Moreover, not only were these authorizations not a response to specific threats, but stops and searches under the authority of ss. 44 and 45 were authorized even before 9/11. In practice an exceptional power intended to be employed on a limited basis has, through administrative action, become quasi-permanent. By contrast, the powers under the old PTA had been used more sparingly. ${ }^{21}$

\section{Judgments}

In the High Court Mr Gillan challenged the exercise of the powers on three grounds. ${ }^{22}$ First, it was contended that Parliament clearly intended that the authorization of the power in s. 44 was to be limited to circumstances where there was judged to be an imminent threat to a specific location and where ordinary police powers were likely to be insufficient. Brooke LJ, who gave the judgment of the court, disagreed. Parliament had clearly intended that an authorization could cover an entire police area and not simply a location as s. 60 of the CJPOA did. ${ }^{23}$ Parliament intended to grant a broad discretion to the appropriate officer because 'a need might crop up at any time for the targeted anti-terrorism patrols, the mobile road checks or the other elements of the anti-terrorism strategy, and it is understandable why, if there is a long-standing general threat, the police wished to be able to exercise these powers anywhere in the police district'. ${ }^{24}$ In deciding to issue an authorization, matters of public safety and national security would need to be considered, and these were matters requiring expertise possessed by the police and Home Secretary. Some degree of deference was therefore required. ${ }^{25}$ The second strand to the application was the contention that the police had acted unlawfully when exercising their ss. 44 and 45 power because in part

21 Home Office, Review of the Operation of the Prevention of Terrorism (Temporary Provisions) Act 1989 (1999) ch. 10 passim. In 1999 s. 13A was used; s. 13B was not.

22 R(Gillan) v Commissioner of the Metropolitan Police [2003] EWHC 2545 (Admin).

23 Section 60(1) provides:

Where a police officer of or above the rank of superintendent reasonably believes that-

(a) incidents involving serious violence may take place in any locality in his area, and

(b) it is expedient to do so to prevent their occurrence, he may give an authorization that the powers to stop and search persons and vehicles conferred by this section shall be exercisable at any place within that locality for a period not exceeding twenty four hours.

24 Above n. 22 at para. 33.

25 Ibid. at para. 35. 
they had insufficient guidance on how to exercise that power. This was an issue which required anxious scrutiny: 'The wider the power, and the more it impinges on personal liberty, the more anxious the court will be to ensure that it is used to achieve the purpose for which it was granted and not for any ulterior or extraneous purpose'.26 However, in the current case there was just enough evidence to show that the powers had not been misused. ${ }^{27}$ Nevertheless, the police needed to review their training and procedures in this area to ensure that the powers were not misused.$^{28}$ The third head of challenge related to the HRA. Notwithstanding the important human rights implications bound up in this case, the High Court summarily dismissed this argument. In Brooke LJ's opinion if any Convention rights were infringed there was adequate textual justification in the European Convention on Human Rights (ECHR) to uphold their compatibility. ${ }^{29}$ Only if the police were using these powers as part of day-to-day policing on the streets of London would there be force in this submission. ${ }^{30}$ Gillan appealed.

The Court of Appeal dismissed the appeal. In essence the Court of Appeal agreed with the High Court but it differed from the decision in the court below in two important aspects. First, the Convention rights points were more fully argued and considered by the Court of Appeal. These were ultimately unsuccessful. However, Lord Woolf CJ made a number of important points in relation to the application of Convention rights. With respect to the applicability of Article 5, the coercive detention on the street for the purposes of a search fell into a grey area under Article 5. ${ }^{31}$ His lordship concluded that in the final analysis 'a short detainment pursuant to a stop and search will normally fall outside Article 5' ${ }^{32}$ Moreover, the scheme contained in the TA could not be said to be arbitrary. ${ }^{33}$ The second point of difference with the High Court was the Court of Appeal's evident unhappiness with the absence of evidence submitted by the respondents by way of justification. ${ }^{34}$ Lord Woolf CJ was rightly concerned with the paucity of evidence. Similarly, Lord Woolf CJ also expressed his concern at the absence of clear directions being given to officers as to how to employ their special powers. The instruction offered was quite simply 'lamentable'. ${ }^{35} \mathrm{Mr}$ Gillan appealed once more.

26 Ibid. at para. 53.

27 Ibid. at para. 58.

28 Ibid. at para. 58.

29 Ibid. at para. 64.

30 Ibid. at para. 63.

31 R(Gillan) v Commissioner of the Metropolitan Police [2005] QB 388 at para. 37.

$32 \mathrm{Ibid}$. at para. 46. His lordship gave no indication of what constitutes an abnormal searchwhich would thus bring Art. 5 into play.

$33 \mathrm{Ibid}$. at para. 49.

$34 \mathrm{Ibid}$. at paras. 51, 54, 55 and 56.

35 Ibid. at para. 53. The instruction consisted of a single PowerPoint slide shown during the officers' daily briefing. 
In his unsuccessful appeal to the House of Lords Gillan raised essentially the same points. In dismissing the appeal the House of Lords handed down a judgment which has important implications for Convention rights and the rule of law. In common with the judgments below, a unanimous House of Lords agreed that the powers in question were indeed sweeping but nevertheless justified given the terrorist threat, which they argued, the United Kingdom currently faces. ${ }^{36}$ There were no grounds for concluding that Parliament intended the powers to be used only where necessary, given the express condition that their use be 'expedient'. The scheme was intended to give the police some degree of flexibility, especially in the post-9/11 environment. The powers were however subject to a 'wide variety of restrictions and safeguards' ${ }^{\prime 37}$ and the possibility of civil action in the case of any alleged misuse. Similarly, the rolling authorizations could not be faulted, complying as they did with the letter of the law. ${ }^{38}$

The applicant's arguments with respect to Convention rights were no more successful. The House of Lords unanimously decided that Article 5 had not been infringed. Lord Bingham concluded that as the procedure was so brief there no deprivation of liberty within the terms of Article 5(1). ${ }^{39}$ But even assuming that there was an interference with the right to liberty then in his lordship's opinion it would be justified within the terms of Article 5(1)(b). ${ }^{40}$ The arguments with respect to Article 8 were similarly rejected. The search did not fall within the terms of Article 8 according to a majority. ${ }^{41}$ Nevertheless, Lord Brown did conclude that privacy rights could be infringed although any interference was justified. ${ }^{42}$ No issue arose under either Article 10 or Article 11.

Before the House two further points were pressed, neither with any success. Firstly, the applicants contended that the regime in ss. 44 and 45 of the TA was inconsistent with the principle of legality contained in the ECHR. ${ }^{43}$ The authorizations were inaccessible not having been published, and the power to stop and search was unfettered, broad

36 Gillan [2006] UKHL 12 at para. 13.

37 Ibid. at para. 74, per Lord Brown.

38 Ibid. at para. 18.

39 Ibid. at para. 25. See also para. 63.

40 Article 5(1)(b) provides:

Everyone has the right to liberty and security of person. No one shall be deprived of his liberty save in the following cases and in accordance with a procedure prescribed by law:

the lawful arrest or detention of a person for non-compliance with the lawful order of a court or in order to secure the fulfilment of any obligation prescribed by law;

41 Above n. 36 at para. 28, per Lord Scott who concluded that an infringement would be 'theoretical'.

42 Ibid. at para.75.

43 Ibid. at para. 32. 
and ill-defined. ${ }^{44}$ Thus the power could be exercised arbitrarily, thereby negating the principle of legality. Lord Bingham was far from persuaded: "The principle of legality has no application in this context $^{\prime}{ }^{45}$ The legislation was detailed, specific and unambiguous. The powers in ss. 44 and 45 were defined with considerable precision. The authorization to bring the power into effect was not law and did not need to be publicized. Indeed, the effectiveness of the provisions may be undermined if there was a requirement to publish. The regime contained sufficient safeguards. ${ }^{46}$ Moreover, in Lord Bingham's opinion, a police officer is not free to act arbitrarily and would be open to civil suit if he did. ${ }^{47}$ In the 'real world a police officer will always have some reason for selecting a particular individual as a person to be stopped and searched'. ${ }^{48}$ The best safeguard according to Lord Hope was to ensure that the powers were properly exercised through guidance and training. ${ }^{49}$

The second additional point on appeal concerned the potentially discriminatory use of the powers. Although ultimately the law lords agreed that no racial discrimination had in fact occurred, they arrived at that conclusion by different reasons. For instance, Lord Scott concluded that the use of the powers disclosed no discrimination on racial grounds and even if it had existed any such use could nevertheless be upheld as lawful within the terms of the Race Relations Act. ${ }^{50}$ However, Lords Hope and Brown were more exercised by this point. As Lord Hope put it, the risk that it will be employed in a discriminatory fashion cannot be discounted entirely' ${ }^{51}$ The decision in the Roma Rights case ${ }^{52}$ stood as a reminder that discrimination on the basis of racial origin was always suspect. Thus a person cannot be selected for a stop and search simply on the grounds of their racial origins even if the search is necessary to prevent terrorism. ${ }^{53}$ The fact that a person is Asian is not a legitimate reason for the exercise of the powers, although ethnicity could be relied upon in drawing up a profile of possible terrorist suspects. ${ }^{54}$ Provided that the powers are exercised in accordance with PACE Code A the power should not be

44 Ibid. at para. 32.

$45 \mathrm{Ibid}$. at para. 15. His lordship considered what his colleagues called legality under the heading of lawfulness.

46 Ibid. at paras. 55-6.

47 Ibid. at para. 35. See also paras. 55 and 57, per Lord Hope.

$48 \mathrm{Ibid}$. at para. 67.

49 Ibid. at para. 57.

50 Ibid. at para. 68; see ss. 41 and 42 of the TA.

51 Ibid. at para. 47.

52 R (European Roma Rights Centre) v Immigration Office at Prague Airport [2004] UKHL 55.

53 Gillan [2006] UKHL 12 at para. 44.

54 Ibid. at para. 91, per Lord Brown. 
discriminatory. ${ }^{55}$ Indeed, while al-Qaeda remained one of the principal terrorist threats to the UK it was inevitable that a disproportionate number of Asian people would be stopped and search under the powers. ${ }^{56}$

While Kevin Gillan was ultimately unsuccessful in his challenge to ss. 44 and 45 of the TA, his case is nevertheless an important one for a number of reasons. First, Gillan's case throws into relief the inevitable tension between the liberty of the individual on the one hand and the counterterrorist requirements of the state on the other. The power in ss. 44 and 45 of the TA places the liberty of every man in the hands of every petty officer ${ }^{57}$ through the adoption of, in effect, a standardless discretion that arguably facilitates arbitrary action. ${ }^{58}$ In such a context it is especially important that the judiciary develops an effective notion of the principle of legality to constrain the scope and exercise of what are, by any measure, exceptional powers. The principle of legality is an integral part of the Convention forming the keystone in the arch supporting the guaranteed rights and freedoms. Without a robust notion of the rule of law underpinning Convention rights and freedoms, the guarantee of rights and freedoms would be essentially theoretical. It is a significant weakness of the decisions that the issue of legality was inadequately dealt with.

\section{The Interpretation of Convention Rights}

In Gillan's case the courts, particularly the House of Lords, interpreted Convention rights in a conservative manner that was overly deferential to the executive. This approach to judicial interpretation is nothing new under the HRA. But Gillan provides yet another clear example of the poverty of thought and simple lack of imagination of the senior British judiciary when deciding difficult cases under the HRA. For example, in reaching its decision the House of Lords was not assisted by Strasbourg authority. The European Court of Human Rights has yet to consider the interaction between Convention rights and police powers to stop and search individuals randomly. Thus their lordships were unable, as they have been in other HRA cases such as Bellinger, ${ }^{59}$ to apply European jurisprudence. ${ }^{60}$ Such circumstances create difficulties for the courts. On the one hand is the admonition for a court under the authority of s. 2 of the HRA not to cast around in the

55 Ibid. at para. 81, per Lord Brown.

56 Ibid. at para. 80, per Lord Brown.

57 The words are those of James Otis on the Writs of Assistance. Quoted in A. Amterdam, 'Perspectives on the Fourth Amendment' (1973-1974) 58 Minn LR 349 at 411.

58 Code A of PACE could possibly have provided some regulation of the exercise of the power, as indeed could the statutory injunction that the power be used only in connection with terrorist crime.

59 Bellinger v Bellinger [2003] UKHL 21.

60 Goodwin v UK (2002) 35 EHRR 88. 
European Human Rights Reports like blackletter lawyers seeking clues ... [but in light of s. 2(1) of the HRA to] . . . draw out the broad principles which animate the Convention' ${ }^{61}$ And on the other hand is the view exposed by Lord Bingham in Ullah where his lordship concluded that a court should not 'without strong reason dilute or weaken the effect of the Strasbourg case law ... it is of course open to member states to provide for rights more generous than those guaranteed by the Convention, but such provision should not be the product of interpretation of the Convention by national courts, since the meaning of the Convention should be uniform throughout the states party to i. . . The duty of national courts is to keep pace with the Strasbourg jurisprudence as it evolves over time: no more, but certainly no less. ${ }^{\prime 2}$ The problem with such a doctrine is that there is a temptation to treat the case law of Strasbourg as offering 'off the peg' solutions to cases. Where there is case law in point this, it might be argued, is not overly problematic. However, reliance on Strasbourg case law brings with it an inherent difficulty. The jurisprudential technique of the European Court of Human Rights has never been to identify explicitly the principles and purposes of the rights and freedoms in the Convention. ${ }^{63}$ The European Court of Human Rights focuses heavily on the facts of the individual applications rather than engaging with the conceptual and philosophical issues underlying them. Consequently the Court has tended not to expound and elaborate its decisions into a coherent body of jurisprudence and as a consequence its case law is rather formulaic. For example, the proportionality test is often applied without a weighing of the limbs of the proportionality test. ${ }^{64}$ The doctrine in Ullah has simply translated these flaws into British human rights jurisprudence, and has been responsible for the impoverished state of domestic human rights jurisprudence of which Gillan is an example. ${ }^{65}$ This approach is explicitly predicated on the justification that the HRA was intended by Parliament to provide a domestic forum for the redress of Convention related claims without the need for an application to Strasbourg. ${ }^{66}$ However, while this is true, for some reason the other intention of the HRA has been ignored. 'Enabling courts in the United Kingdom to rule on the application of the Convention', the White Paper, Rights

61 Aston Cantlow and Wilmcote with Billesley Parochial Church Council v Wallbank (2001) Ch 51 at para. 44, per Morritt V-C.

62 R (Ullah) v Special Adjudicator [2004] UKHL 26, [2004], 2 AC 323, at para. 20 per Lord Bingham.

63 A. McHarg, 'Reconciling Human Rights and the Public Interest: Conceptual Problems and Doctrinal Uncertainty in the Jurisprudence of the European Court of Human Rights' (1999) 62 MLR 671 at 673.

64 Ibid. at 687.

65 There are other cases where this tendency is in evidence: Secretary of State for Work and Pensions v M [2006] UKHL 11; Attorney-General's Reference (No. 2) of 2002 [2004] UKHL 43; Attorney-General's Reference (No. 1) of 2001 [2003] UKHL 68; and R (S) v Chief Constable of South Yorkshire [2004] UKHL 39.

66 See for example $R(S)$ v Chief Constable of South Yorkshire [2004] UKHL 39. 
Brought Home argued, 'will also help to influence the development of case law on the Convention by the European Court of Human Rights on the basis of familiarity with our laws and customs and of sensitivity to practices and procedures in the United Kingdom . . . Our courts' decisions will provide the European Court with a useful source of information and reasoning for its own decisions' ${ }^{67}$ In practice the doctrine in Ullah not only frustrates that intention, it has the left the courts without the intellectual tools to reason adequately in human rights cases. ${ }^{68}$

\section{i. The Right to Liberty and Freedom of Movement}

Mr Justice Holmes once remarked that it is one of the misfortunes of the law that ideas become encysted in phrases and thereafter for a long time cease to provoke further analysis' ${ }^{69}$ The jurisprudence of the European Court of Human Rights with respect to Article 5 is a good example of such a phenomenon. The leading case, Guzzardi v Italy, ${ }^{70}$ is frequently applied in an almost mechanical fashion. And this is problematic since the test that the European Court of Human Rights enunciated under Article 5 for determining whether or not there has been a deprivation of liberty provides 'neither bright-line rule nor anything that begins to approximate to a clear definition' ${ }^{71}$ The European Court of Human Rights simply unhelpfully asserted, and has continued to do so ever since, that the difference between deprivation of and restriction upon liberty is nonetheless merely one of degree or intensity, and not one of nature or substance'. ${ }^{72}$ Such an elastic definition provides little concrete guidance as to how it might apply in different contexts. In practice the Guzzardi test provides an almost open-ended judicial discretion for the application of Article 5. This characteristic of the jurisprudence is, no doubt, what exercised Sir Gerald Fitzmaurice to dissent in Guzzardi. Applying this nebulous test in Guzzardi the European Court of Human Rights extended Article 5 to cover a situation that was more properly dealt with by Article 2 of Protocol 4.

With such limited guidance it is perhaps not surprising that British courts have struggled when applying Article 5. Indeed, given the flaws of European case law in this context it is arguable that British courts could make a useful contribution to the development of Convention jurisprudence by injecting some analytical rigour. However, in Gillan instead of approaching the interpretation of Article 5 afresh and reasoning from principle, the House of Lords simply applied by

67 Rights Brought Home: The Human Rights Bill, Cm 3782 (1997) para. 1.18.

68 See above n. 64

69 Hyde v US 225 US 347 at 391 (1912).

70 [1980] ECHR 7367/76.

71 Chaskalson et al., Constitutional Law of South Africa (Juta: Cape Town, 2006) para. 40-33.

72 [1980] ECHR 7367/76 at para. 88. 
analogy the 'encysted phrases' of Guzzardi v Italy. ${ }^{73}$ No doubt because our courts believe they are duty bound to follow the jurisprudence of the European Court of Human Rights, no attempt was made to look for the underlying purpose of Article 5 or indeed to consider whether the security interests of the individuals had been adversely affected. Although we are told that the HRA is a constitutional instrument, being in effect a British bill of rights, ${ }^{74}$ little attempt has been made to interpret it as such by the higher judiciary. In almost every comparable jurisdiction courts, when faced with such issues, begin with a purposive interpretation of the extent to which any constitutional guarantee applies. The purpose of a constitutional guarantee is to be understood in light of the interests that it is designed to protect. And this analysis is to be undertaken, and the purpose of the right or freedom in question is to be sought by reference to the character and larger objects of the Charter itself, to the language chosen to articulate the specific right or freedom, to the historical origins of the concept enshrined, and where applicable, to the meaning and purpose of the other specific rights and freedoms with which it is associated within the text of the charter' ${ }^{75}$ Moreover, it is axiomatic that as it is a constitution that is being interpreted, the guarantees must be read and interpreted in a generous manner. ${ }^{76}$ However, British courts have treated these principles as mere shibboleths that can be occasionally recited, and then safely ignored. In Gillan there was no attempt to interpret Article 5, or indeed the other applicable Convention rights, purposively. Indeed it is hard to say that any of the applicable Convention rights were by any standard interpreted generously. There is a clear danger here that unless the HRA is interpreted as a constitu-

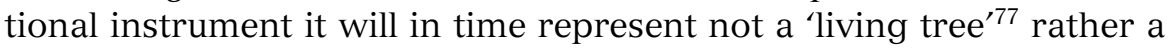
judicial bonsai.

The adherence to the rule in Ullah's case meant that a wealth of useful authority was overlooked. Although the European Court of Human Rights has not considered the issue of whether a police stop and search interferes with Convention rights, the issue has been

73 Subsequently, the absence of full and proper analysis in Guzzardi has generated more forceful criticism from members of the House who did not sit in Gillan. See for example the Home Secretary v JJ [2007] UKHL 45 at para. 30; per Lord Hoffmann (dissenting) and para. 80, per Lord Carswell (dissenting). In the end, notwithstanding the criticisms Guzzardi was followed and applied. This led to the bizarre situation where being subject to a control order under the Prevention of Terrorism Act 2005 (c.2) for more than 16 hours per day was incompatible with Art. 5 (para. 108, per Lord Brown). It is difficult to resist the conclusion that the figure of 16 hours was arrived at on anything other than a largely subjective basis.

74 McCartan Turkington Breen v Times Newspapers [2000] 3 WLR 1670 at 1686, per Lord Steyn.

$75 R$ v Big M Drug Mart [1985] 1 SCR 295 at para. 117, per Dickson J.

76 Minister of Home Affairs v Fisher [1979] 3 All ER 21 at 25, per Lord Wilberforce.

77 Edwards v Attorney-General of Canada [1930] AC 134 at 136, per Lord Sankey LC. Tryer v UK [1978] ECHR 5856/72 at para. 31. 
considered in other jurisdictions. ${ }^{78}$ In Gillan the House of Lords concluded that the powers in the TA were more an interference with freedom of movement than the right to liberty. The interference with the right to freedom of movement by random stops was considered by the Zimbabwean Supreme Court in Elliot v Commissioner of Police. ${ }^{79}$ In Elliot the Supreme Court was asked to consider whether the absolute and uncontrolled discretion to stop members of the public randomly and demand the production of their identity cards was consistent with the Constitution. Under s. 10 of the Zimbabwean National Registration Act any person who failed to produce their identity card was guilty of an offence. ${ }^{80}$ Gubbay CJ held that the impunged provisions infringed the constitutional guarantee to freedom of movement. The power in s. 10 permitted a random stop. The section did not specify any grounds or cause for stopping the person. Consequently it could be employed in an entirely arbitrary manner. An officer could act on his own whim and out of malice or spite. As Gubbay CJ observed:

individual police officers will have different reasons. Some may tend to stop the young, others the elderly; some only men, others women; some the poorly attired, others those with the outward appearance of affluence; some those who are jacketless, others those without handbags; and so on. Racial considerations may even be a factor. If it is unnecessary that the stoppage be based upon reasonable suspicion that the person is not carrying an identity document and that all the police officer need say is 'I stopped him because I was seeking persons without identity documents', how many innocent persons will be so accosted to apprehend one without an identity document? ${ }^{81}$

His lordship went on to conclude that simply because an officer was acting within the law did not mean he is not doing so arbitrarily. There was 'no essential link between the two concepts'. ${ }^{2}$ A random stop under the power no matter how brief and for whatever purpose was a detention, and thus an infringement of the right of freedom of movement. ${ }^{83}$ And as this infringement could not be justified on the grounds of public order the section was unconstitutional. However,

78 The European Commission of Human Rights (hereafter the Commission) in $B \mathrm{v}$ France 10179/82 13/05/87 DR 52 at 120 did consider the compatibility of the French law that required a person to produce proof of identity in limited circumstances and thereafter to detain a person at a police station for up to six hours while their identity was confirmed. The Commission held (at 126) that this was compatible with Art. 5(1)(b) representing a 'fair balance' between the right to liberty and an obligation prescribed by law. The Commission declined to decide whether there had been a deprivation of liberty within the terms of Article 5 on the basis that the law covered the situation that the applicant complained of. See further at $125-6$.

79 [1997] 3 LRC 15.

80 National Registration Act (Statutes of Zimbabwe: Ch. 10:17, s. 10(1)(c).

81 Above n.78 at 19.

82 Ibid.

83 Ibid. 
while freedom of movement is not a Convention right, it is nonetheless a right at common law. ${ }^{84}$ Yet there was no consideration of this by their lordships.

Be that as it may, the difference between liberty and freedom of movement is one of degree. It is arguable that the House of Lords was wrong to conclude that the power in ss. 44 and 45 does not affect the right to liberty. ${ }^{85}$ For instance, Lord Bingham concluded that an individual subject to the powers in ss. 44 and 45 would be 'detained in the sense of kept from proceeding or kept waiting ... . [but] there [would be] no deprivation of liberty' ${ }^{86}$ This is quite simply wrong. Article 5 is a right with a considerable pedigree. The possibility of arbitrary interference with the liberty of the subject has long been a central concern of English common law. Blackstone, for instance, observed that:

the law of England regards, asserts, and preserves the personal liberty of individuals. This personal liberty consists in the power of locomotion, of changing situation, or removing one's person to whatsoever place one's own inclination may direct; without imprisonment or restraint, unless by due course of law ... [The] confinement of the person, by secretly hurrying him to gaol, where his sufferings are unknown or forgotten is a dangerous engine of arbitrary government ... [Moreover] the confinement of the person, in any way, is an imprisonment. So that the keeping a man against his will in a private house, putting him in the stocks, arresting or forcibly detaining him in the street, is an imprisonment. ${ }^{87}$

For Blackstone the right to liberty and the right to personal security were absolute or primary rights necessary for freedom. ${ }^{88}$ Similarly Dicey concluded that the right to personal liberty as understood in England means in substance a person's right not to be subjected to imprisonment, arrest, or other physical coercion in any manner that does not admit of legal justification'. ${ }^{89}$ This English heritage has clearly been transposed into Article 5 for, as the European Court of

$84 R$ v Secretary of State for the Home Department, ex p. MacQuillan [1995] 4 All ER 400 at 421, per Sedley LJ. R (Craven) v Secretary of State for the Home Department [2001] All ER (D) 74 at para. 35: 'Freedom of movement is a fundamental value of the common law and I would add of the Convention', per Buxton LJ. Of course as a common law right, freedom of movement can be limited by statute. However, such rights can only be limited by express wording or necessary implication. $R \mathrm{v}$ Secretary of State for the Home Department, ex p. Simms [2000] 2 AC 115 at 131, per Lord Hoffmann. This is a feature of the 'intermediate constitution'. See Laws LJ in International Transport Roth Gmb v Secretary of State for the Home Department [2002] EWCA Civ 158 at para. 71.

85 Gillan [2006] UKHL 12 at para. 25, per Lord Bingham.

86 Ibid.

87 Sir William Blackstone, Commentaries on the Laws of England (Clarendon, Oxford: 1765-1769) Book 1, ch. 1, 131-2. Emphasis added.

88 A. W. B. Simpson, Human Rights and the End of Empire (OUP: Oxford, 2001) 29-30.

89 A. V. Dicey, An Introduction to the Law of the Constitution (OUP: Oxford, 1886) 207-8. The TA, of course, provides legal justification in a narrow sense. However, because ss. 44 and 45 create a standardless discretion, in effect no justification is required. 
Human Rights has made consistently clear, that Article is intended to protect individuals from arbitrary deprivations of their physical liberty. ${ }^{90}$ Article 5 of the ECHR is a guarantee of 'individual liberty in its classic sense, that is to say the physical liberty of the person . . . its aim is to ensure that no one should be dispossessed of this liberty in an arbitrary fashion'. ${ }^{91}$ The "protection against arbitrary arrest and detention', contained in Article 5, concluded the European Commission of Human Rights, "was one of the principal considerations of the drafters of this treaty'. ${ }^{92}$ That concern created a strong right that is one of the 'first rank' rights that protect the individual in a democratic society. ${ }^{93}$ Consequently, Article 5 is subject only to a set of very narrow and specific limits. In essence Article 5 is the classic articulation of the protection of physical liberty through a bodyguard of legality. Furthermore, as the text makes clear, Article 5 extends to the protection of both the liberty and security of the individual. While the security interests of the individual have received little attention from the European Court of Human Rights over the years, nevertheless what case law exists does allow two important conclusions to be drawn. ${ }^{94}$ First, the type of 'security' interests contemplated by Article 5(1) are those which are related to the physical liberty interests of the individual. Second, the guarantee of 'security' is in essence a protection against the arbitrary interference with the physical liberty guaranteed by Article $5 .{ }^{95}$ Moreover, as the text makes clear, the framers of the ECHR clearly intended that Article 5 apply to situations that were not arrests because, although an arrest includes detention, detention does not necessarily include arrest. ${ }^{96}$ There are a range of situations where agents of the state conduct coercive procedures, which are not arrest, but which involve the restraint or control of an individual, ${ }^{97}$ preventing people going where they please. Thus not every deprivation of liberty is an arrest. ${ }^{98}$ Detention includes an element of state compulsion, which might include but is not limited to arrest, but which nevertheless interferes with the physical liberty and security of the individual. At one end of the spectrum detention might include forcible admission to a hospital under the Mental Health Act, whereas at

90 Luckanov v Bulgaria [1997] ECHR 21915/93 at para. 41. Assanidze v Georgia [2004] ECHR 71503/01 at para. 171.

91 Engel v Netherlands [1981] ECHR 5100/76 at para. 58.

92 East African Asians v United Kingdom (1973) DR 78 at para. 222.

93 Along with with Arts. 2, 3 and 4. See McKay v United Kingdom [2006] ECHR 543/03 at para. 30.

94 Khudoyorov v Russia [2005] ECHR 6847/02 at para. 142.

95 See $A$ and others v FRG 5673/72, 5670/72 and 7729/76 at para. 28. X v FRG 8334/78 (1981) 24 DR 103 at 107 para. 3.

96 For a similar reading of s. 2(c) of the Canadian Bill of Rights see Chromiak v The Queen [1980] 1 SCR 471, at para. 13, per Ritchie J. See also R v Goodwin (1993) 2 NZLR 153 at 200, per Hardie Boys J.

97 Or the reasonable apprehension that such restraint or control will be applied.

98 R v Goodwin (1993) 2 NZLR 153 at 173, per Cooke P, at 188, per Richardson J, at 200, per Hardie Boys J. 
the other end it could include short-lived interferences such as compulsory blood tests ${ }^{99}$ or stops and searches. However, on the basis of the decision in Gillan, one might conclude that Article 5 applied only to arrests and not simply detentions in the context of criminal justice. ${ }^{100}$ Yet in the context of a stop under the TA a refusal to submit to a police officer's order to submit to a search constitutes a criminal offence, as does wilfully obstructing such a search. ${ }^{101}$ Both are punishable by imprisonment. ${ }^{102}$ As Lord Bingham observed in Gillan, a member of the public is under a duty not to obstruct a police officer who is conducting a search within the terms of the Act. ${ }^{103}$ There can be little doubt that the right to liberty is implicated by laws which impose imprisonment as a penalty for their non-observance'. ${ }^{104}$ For example, in The Queen v Therens the Supreme Court of Canada had to determine whether there had been a deprivation of liberty for the purposes of the Canadian Charter when a car driver was requested to undertake a breathalyser test by a police officer under the provisions of the Criminal Code. If there had been a deprivation of liberty then the defendant would be entitled, it was argued, to the assistance of counsel as required by s. 10 of the Charter of Rights and Freedoms. ${ }^{105}$ In deciding that there had been a deprivation of liberty Le Dain J held that a detention for the purposes of the Charter occurred in three situations. First, when there is a deprivation of physical liberty through the application of physical constraint. Second, 'when a police officer or other agent of the state assumes control over the movement of a person by a demand or direction which may have significant legal consequences'. ${ }^{106}$ And thirdly, where the individual is subject to 'psychological compulsion in that the individual acquiesces because he reasonably believes that he has no choice but to submit'. ${ }^{107}$ The common theme running throughout all these situations is that 'there must be some form of compulsion or coercion to constitute an interference

99 X v Austria (1979) DR \& R 154 at 156. App No. 8278/78. “The Commission is of the opinion that enforcing a blood test on a person is a deprivation of liberty even if this deprivation is of very short length'. The requirement to provide a blood sample was compulsory in paternity cases.

100 See also Austin v Commissioner of the Metropolitan Police [2007] EWCA Civ 989, CA where the Court of Appeal held that where an individual was detained in Oxford Street, London by the police for a period of seven and a half hours Article 5 was not infringed.

101 At common law the individual is under no compulsion to comply with a request to stop and answer questions. Indeed, in the absence of any positive legal authority any detention would be an unlawful imprisonment. $R$ v Goodwin (1993) 2 NZLR 153 at 163, per Cooke P.

102 TA, s. 47.

103 Gillan [2006] UKHL 12 at para. 26.

104 Ferreira v Levin NO [1996] 3 LRC 527 at para. 179, per Chalksason P.

105 Section 10 provides a number of rights, such as the right to counsel, to be granted to individuals arrested or detained.

106 The Queen v Therens [1985] 1 SCR 613 at para. 53. Dissenting, but not on this point.

$107 R$ v Lewis (2007) 250 NSR (2d) 283 at para. 21, per Fichaud J. 
with liberty'. ${ }^{108}$ Thus when faced with a request, a demand or direction from an agent of the state, does a person reasonably regard himself as free to refuse ${ }^{109}$ Criminal liability for refusing to comply is in effect compulsion and thus engages the right to liberty: ${ }^{110}$ 'any criminal liability for failure to comply with a demand or direction of a police office must be sufficient to make compliance involuntary'. ${ }^{111}$ As was noted above, Lord Bingham concluded that a person stopped under the authority of ss. 44 and 45 was not detained but merely kept waiting. On reflection this view cannot stand. To begin with, the fact that the stop was likely to be short-lived is a separate issue from whether or not the detention is arbitrary. Whether or not the stop was arbitrary should have warranted separate consideration under Article 5. Furthermore, a person who is required to stop his car by a red traffic light is kept waiting. After a short delay he is allowed on his way. No doubt some might argue that this too is an interference with the right to liberty. After all, an individual who ignores a red light and drives through risks not only an accident but also a conviction under the road traffic laws. However, such regulation differs in two important aspects from the power in the TA. First, under the TA there is a direct assumption of the control of a specific individual rather than the universal regulation of a class of people. Second, the TA powers are a direct gateway to the criminal justice process. A power to stop and search an individual is intended, in part, to discover evidence of criminality. As with Mr Funke, albeit in a slightly different context, individuals stopped under the TA power enjoy a Hobsonian choice. ${ }^{112}$ Either they submit to the search and its attendant risks or they resist and face the possibility of a criminal conviction. Of course it is most unlikely that the average citizen is aware of their exact legal position and it is likely that, when faced with such a demand from a police officer, he or she will comply rather than risk assault or arrest for obstruction. Psychological compulsion in such circumstances can make the restraint of liberty involuntary and thus amount to a deprivation. ${ }^{113}$ Police stops are inherently coercive, both legally and psychologically. ${ }^{114}$ It is, of course, important that in seeking to interpret the right purposively we do not overshoot that purpose through an overgenerous interpretation. Clearly, an overgenerous interpretation of Article 5 to cover a large number of temporary and transitory interferences with the right to liberty might hamper the effectiveness of law enforcement. Therefore in the absence of direct coercion to the

108 Ibid. at para. 22.

109 Therens, above n.105 at para. 54.

110 Ibid. at para. 56.

111 Ibid.

112 Funke v France [1993] ECHR 0828/84.

113 Therens, above n.105 at para. 57 .

114 All the more so for minority groups for whom they are particularly humiliating, frightening and degrading. D. Tanovich, 'Using the Charter to Stop Racial Profiling' (2002) 48 Osgoode Hall LJ 145 at 163. 
individual, Article 5 will clearly not apply. Thus, for example, when you stop at the traffic lights Article 5 will not be engaged. But at the same time we must not lose sight of the fact that a narrow interpretation would render the protection afforded by Article 5 theoretical and illusory'. ${ }^{115}$ Moreover, as one of the principal purposes behind Article 5 is to prevent arbitrary deprivations of liberty, setting a high threshold for the engagement of Article 5 effectively removes from scrutiny areas of low-level discretionary powers that have historically been abused.

\section{ii. Privacy}

Leaving Article 5 to one side, with respect to the Article 8 right to privacy a more expansive interpretation was also possible for, as Feldman correctly observes, 'a personal search in public is a particularly embarrassing and upsetting experience . . . it is also a major interference with people's right to privacy'. ${ }^{116}$ The European Court of Human Rights has repeatedly held that the right to privacy is a broad concept 'not susceptible to exhaustive definition', depending in large part on a determination of what reasonable expectation of privacy a person enjoys in a particular context. The privacy interests protected do not necessarily have to be the core ones envisaged by Article 8 for that guarantee to be engaged. Thus in certain circumstances a person will enjoy a right to privacy in public. ${ }^{117}$ Here American law offers an interesting perspective. Textually the Fourth Amendment is, of course, very different from the provisions of the ECHR: 'The right of the people to be secure in their persons ... against unreasonable searches and seizures, shall not be violated'. Thus American jurisprudence might seem to be of limited utility. However, the interests that it protects are broadly the same as those protected by the ECHR in this context. Just as Articles 5 and 8 protect the liberty/security and privacy interests of the individual so does the Fourth Amendment. ${ }^{118}$ The Fourth Amendment not only protects individuals from unreasonable searches which interfere with their legitimate privacy interests but also their liberty/security interests. ${ }^{119}$ For instance the US Supreme Court has long held that "no right is held more sacred or is more carefully guarded by the common law than the right of every individual to the possession and control of his own person free from all restraint or interference of others'. ${ }^{120}$ Thus in Terry v Ohio the US Supreme Court held that the right to security guaranteed by the

115 See Chaskalson et al., above n. 70 at paras. 40-33 to 40-34.

116 D. Feldman, Civil Liberties and Human Rights in England and Wales, 1st edn (OUP: Oxford, 1993) 176.

117 Peck v United Kingdom [2003] ECHR 44647/98. Perry v United Kingdom [2004] ECHR 63737/00 at paras. 36-7.

118 This is not surprising, given the American experience with the same Writs of Assistance that bedevilled Wilkes and others.

119 Boyd v US 116 US 616 at 630 (1886).

120 Union Pacific Railway Co v Botsford 141 US 250 at 251 (1891). 
Fourth Amendment 'belongs as much to the citizen on the streets of our cities as to the home owner closeted in his study to dispose of his secret affairs'. ${ }^{121}$ When a person is accosted by a police officer and prevented from walking away then for the purposes of the Fourth Amendment he has been seized. ${ }^{122}$ The US Supreme Court has emphatically rejected a de minimis approach whereby such stops were not to be considered arrests for the purposes of the Constitution. As the Court observed, such stops and searches when conducted in the street are not simply a petty indignity being 'a serious intrusion on the sanctity of the person which may inflict great indignity and arouse strong resentment, and it is not to be undertaken lightly'. ${ }^{123}$ Furthermore, the US Supreme Court has held that bags and luggage enjoy constitutional protection under the Fourth Amendment. Indeed bags enjoy a greater expectation of privacy than cars for, as the Supreme Court observed, luggage is intended as a repository of personal effects' ${ }^{\prime 24}$ It therefore seems reasonable that a person enjoys a reasonable expectation of privacy for materials carried in a bag, which might range from the mundane to the highly intimate.

Privacy rights under Article 8 are also implicated by the recording and storage of data relating to the exercise of the powers under the TA. Every such stop and search has to be recorded by law. In conducting the stop and search an officer will fill out Form 5090. On that form he is required to note the ethnic group of the detainee, and he must also ask for that person's name, address and date of birth. ${ }^{125}$ Copies of Form 5090 are subsequently fed into the 'Stops Database'. ${ }^{126}$ No doubt the 'Stops Database' is invaluable in assisting senior officers to comply with their duty to produce reports on the use of stop and search powers. ${ }^{127}$ However, this form of systematic recording and storage of personal information relating to identity ${ }^{128}$ has been held by the European Court of Human Rights to infringe the right contained in Article $8(1),{ }^{129}$ even if the information is in the public domain. ${ }^{130}$

121392 US 1 (1968).

122 Ibid. at 16.

123 Ibid. at 17.

124 US v Chadwick 433 US 1 at 13 (1979).

125 PACE Code A Part 4.

126 See http://www.met.police.uk/foi/pdfs/policies/stop_and_account_sop.pdf.

127 PACE Code A Part 5.

128 Defined in Art. 2 of the Convention for the Protection of Individuals with regard to Automatic Processing of Personal Data as 'any information relating to an identified or identifiable individual'. See further Amann v Switzerland [2000] ECHR 27798/95 at para. 65.

129 Amann v Switzerland [2000] ECHR 27798/95, at paras. 65-7. Rotaru v Romania [2000] ECHR 28341/95 at paras. 43-4. The Court has relied upon the provisions of the Convention for the Protection of Individuals with regard to Automatic Processing of Personal Data when interpreting Art. 8 of the ECHR. < http:/ /conventions.coe.int/Treaty/en/Treaties/Html/108.htm >

130 Rotaru v Romania [2000] ECHR 28341/95 at para. 43. 
Article 8 is, of course, a qualified right, and a breach of Article 8 would only follow if the TA could not be saved under Article 8(2). For a measure to be upheld under Article 8(2) the state must show that the impugned measure has a legitimate aim, is necessary in a democratic society and is prescribed by law. ${ }^{131}$ In the shadow of recent terrorist attacks no one could seriously argue that the TA does not pursue a legitimate aim. The provisions of the Act are clearly justified as necessary for the prevention of crime or to protect the national security interests of the United Kingdom. That is not in doubt. However, Article 8(2) does not grant a state carte blanche to do whatever it considers necessary. In other words the powers must be proportionate. However, where the powers wielded by the state are exceptional in nature then a higher standard of scrutiny is required. In Klass $\mathrm{v} F R G{ }^{132}$ for example, the applicants had their communications intercepted and monitored under German law. They complained that this constituted an interference with the right to privacy guaranteed by Article 8. The European Court of Human Rights did not agree, holding that the interference was justified. Nevertheless in dismissing the application the European Court of Human Rights made a number of important observations. To begin with the Court noted that in the age of increasingly sophisticated terrorism a state must be able to take measures to counter such threats effectively. ${ }^{133}$ Thus exceptional powers may, at times, be justified. Nevertheless, the state does not enjoy an unlimited discretion in such matters. Critically states must not rely on pleas of necessity in the context of counterterrorism to adopt measures that undermine democracy rather than protect it. Such security measures are only tolerable in a democracy so far as is strictly necessary. ${ }^{134}$ Exceptional measures must therefore be accompanied by effective safeguards to ensure that they are not abused. ${ }^{135}$ Simply because the context is challenging this does not license the state to adopt permissive discretionary powers in the absence of effective safeguards.

\section{iii. Freedom of Expression}

Moreover, in practice the powers in the TA can act as a form of indirect prior restraint. ${ }^{136}$ The immediate purpose of the powers is the detection and prevention of terrorism. However, the powers can also be used for a secondary purpose: that is, restraining speech, as the

$131 R$ (Daly) v Secretary of State for the Home Department [2001] UKHL 26 at para. 27, per Lord Steyn.

132 Klass v FRG [1979] ECHR 5029/71.

133 Ibid. at para. 49.

134 Ibid. at para. 42.

135 Ibid. at paras. 49-50.

136 T. Emerson, 'The Doctrine of Prior Restraint' (1954) 20 Law and Contemporary Problems 648 at 656. 
experiences of both Messrs Gillan and Wolfgang amply demonstrate. ${ }^{137}$ Of course such an exercise of the power in ss. 44 and 45 TA is unlawful. However, because the power is permissive it facilitates such actions with, in practice, a considerable degree of impunity. In theory an ex post facto remedy is available, though in practice it is of little value especially to someone who wishes to attend a protest, and who is impeded by an officer exercising the ss. 44 and 45 power. ${ }^{138}$ Indirectly, it seems reasonable to conclude that the power can chill public protest. ${ }^{139}$ This line of reasoning might seem somewhat strained to some. However, it is worth bearing in mind the Cases of the General Warrants. In Wilkes v Wood John Wilkes MP famously struck a blow for liberty and legality in the face of unlimited powers of search and seizure. ${ }^{140}$ The King's Messengers and a constable entered Wilkes's house under the authority of a general warrant searching for evidence to support seditious libel proceedings against the MP. Wilkes subsequently brought and won an action for trespass. In the course of his judgment Pratt CJ concluded that a general warrant which vested in the representatives of the King a discretionary power to search wherever their suspicions fell was totally subversive of the liberty of the subject'. ${ }^{141}$ In the related case of Huckle $v$ Money ${ }^{142}$ which arose from the same events, his lordship was even more forthright: 'To enter a man's house by virtue of a nameless warrant in order to procure evidence is worse than the Spanish Inquisition; a law under which no Englishman would wish to live an hour; it was a most daring public attack upon the liberty of the subject . . . I thought that the 29th Chapter of Magna Charta, which is pointed against arbitrary power, was violated'. These cases are interesting not simply because they warn against unbridled discretionary police power, but also because at their core they concern free speech. Although primarily concerned with the legality of searches, the government would have been unable to bring prosecutions for seditious libel without such documentary evidence. Thus, as Stuntz contends, these cases were 'classic First Amendment cases in a system with no First Amendment and no vehicle for direct substantive judicial review'. ${ }^{143}$ In this sense the TA

137 In the joined appeal in Gillan the appellant was so distraught at being stopped and searched by the police that she left the area and did not attend the planned protest.

138 In a free and democratic society there is a strong argument that citizens should not be put to the expense and bother of bringing legal proceedings to vindicate their basic constitutional rights.

139 In certain circumstances threats to prosecute have been viewed as inappropriate prior restraint in the USA. See for example Council for Periodical Distributers v Evans 642 Fed Sup 552 (MD Ala 1986). Reasoning affirmed 827 F 2d 1483 (11th Cir 1982).

140 (1763) 98 ER 489.

141 Wilkes v Wood (1763) 98 ER 489 at 498.

142 Huckle v Money (1763) 2 Wils 205 at 206.

143 W. J. Stuntz, 'The Substantive Origins of Criminal Procedure' (1996) 105 Yale Law Journal 393 at 403. See also A. R. Amar, The Bill of Rights (Yale: New Haven, 1998) 75-6. 
power is thus a good example of the unintended effect of emergency legislation. As Waldron notes, such emergency powers are often used for other forms of state regulation unrelated to their original counterterrorist purpose. ${ }^{144}$ Yet in Gillan the possibility that the powers in the TA might be used to restrict free speech were dismissed as remote. ${ }^{145}$

\section{The Principle of Legality: the Problem of Permissive Powers}

The rule of law is an inherent part of the Convention scheme for the protection of rights and freedoms. For legislative acts to comply with the requirements imposed by the rule of law, a law must provide a measure of protection against arbitrary interferences by public authorities with Convention rights and freedoms. ${ }^{146}$ Nowhere is this requirement more important than Article 5. The principle of legality is an essential part of the architecture of Article 5. Article 5 states that 'no one shall be deprived of his liberty save in the following cases and in accordance with a procedure prescribed by law ... [for] the lawful arrest or detention of a person ... in order to secure the fulfilment of any obligation prescribed by law'. The House of Lords concluded that because the obligation to stop was imposed by virtue of the TA this complied with the requirement that the procedure be "prescribed by law'. In a procedural sense their lordships were quite correct. However, the concept of legality contained in the Convention requires more than simply legal authority to interfere with the liberty of the individual. ${ }^{147}$ Such a narrow conception of legality would do little to prevent the arbitrariness that Article 5 is intended to prevent. Thus the European Court of Human Rights insists that legality has both procedural and substantive aspects. The Convention requires that the law be sufficiently accessible and precise in order that arbitrary applications can be avoided. ${ }^{148}$ 'Where the deprivation of liberty is concerned', the European Court of Human Rights concluded in Khudoyorov v Russia, it is particularly important that the general principle of legal certainty be satisfied'. ${ }^{149}$ Permissive laws that authorize interferences with liberty without any adequate conditions precedent or controlling criteria are liable to fall foul of the legality

144 J. Waldron, 'Security and Liberty: The Image of Balance' (2003) 11 Journal of Political Philosophy 191 at 205: 'The protection of civil liberties is not just a matter of cherishing certain freedoms that we particularly value . . It is also a matter of suspicion of power, an apprehension that power given to the state is seldom ever used only for the purposes for which it is given, but is always and endemically liable to abuse'.

145 Gillan [2006] UKHL 12 at para. 30, per Lord Bingham.

146 Tysiac v Poland [2007] ECHR 5410/03 at para. 112.

147 Elliot v Commissioner of Police [1997] 3 LRC 15 at 19, per Godwin CJ.

148 Amur v France [1998] 22 EHRR 553 at para. 50.

149 [2005] ECHR 6847/02 at para. 125. 
requirement. In the context of stop and search powers the usual safeguard has traditionally been the requirement of a 'reasonable suspicion' on the part of the police officer. ${ }^{150}$ Such a criterion, in theory at least, not only limits and controls the employment of intrusive powers to situations where society's interests in the detection of crime outweigh those of the individual, but also prevents abuse by providing an objective standard against which an officer's conduct can ex post facto be measured. The TA lacks this criterion. ${ }^{151}$ The power in the TA is limited only by Parliament's command that it be used 'only for the purpose of searching for articles of a kind which could be used in connection with terrorism' ${ }^{152}$ The potential for hidden abuse is thus largely because the law delegates to the officer a power with no adequate basis of control. In the absence of an effective controlling criterion the law makes Convention rights dependent on the exemplary behaviour of police officers.

Before the Court of Appeal and the House of Lords counsel for the applicants in Gillan had sought to argue that the power in the TA was not 'prescribed by law' in that it was imprecise and vague. This argument was bound to fail for, as Lord Bingham observed, the TA 'defines and limits the powers with considerable precision'. ${ }^{153}$ However, both counsel and the Bench missed the essential point with respect to legality. The power is not vague; rather it is permissive. In this context the key question is, 'are there sufficient safeguards in the TA to protect Convention rights?'. The permissiveness of a provision in these circumstances means rather than preventing abuse, it actually facilitates it. The power may be used for purposes beyond those licensed by Parliament without any effective legal oversight or redress. The power authorizes arbitrary interferences with Convention rights that are in effect not 'prescribed by law'. In Vasileva v Denmark the European Court of Human Rights held that a power to authorize detentions should not be used in a punitive manner outside its intended purpose. ${ }^{154}$ Similarly, in the South African case $S$ v $Z^{155}$ the applicants were a number of juvenile offenders who had been sentenced to reform school but because of systemic failures had been kept in penal custody instead. The Eastern Cape High Court concluded that deprivation of their liberty was arbitrary and thus, because it fell outside the purpose for which it was imposed, inconsistent with the constitutional guarantee to liberty. ${ }^{156}$ Indeed, with permissive powers the danger that they will be abused in this manner is even greater as the case

150 Fox, Campbell and Hartley v The United Kingdom [1989] ECHR 12244/86.

151 TA, s. 45(1)(b).

152 Ibid., s. 45(1)(a).

153 Gillan [2006] UKHL 12 at para. 35.

154 Vasileva v Denmark (2003) 15 BHRC 246.

155 CA 40/2003; 2004 (4) BCLR 410 (E).

156 Ibid. at para. 21, per curiam. 
of Walter Wolfgang illustrates. ${ }^{157}$ The detention of an individual for heckling at a private function where there was no evidence of a terrorist connection was clearly punitive and in no way connected with the detection or prevention of terrorist crime. When a power can be used for an inappropriate purpose it can be used arbitrarily.

Indeed, rather than vindicating the requirement inherent in the Convention that restrictions on rights be in harmony with the principle of legality, a permissive power subverts that principle. Such powers allow for pretextual stops. In other words an individual is stopped on the pretext of counterterrorist reasons but in reality the stop is for other purposes. Such a power, in the absence of effective safeguards, carries with it an ever-attendant danger that it will be exercised arbitrarily. Although the term 'arbitrary' has been frequently cited it has not received much judicial clarification either in the European Court of Human Rights or courts applying the HRA. However, what constitutes arbitrariness has received greater consideration under the International Covenant on Civil and Political Rights (ICCPR) and domestic bills of rights based on its provisions. ${ }^{158}$ This jurisprudence is most instructive. At the outset the term arbitrary was included in order to cover acts that may be lawful in the sense that they were consistent with the law but which were nevertheless unjust. ${ }^{159}$ Indeed, the term was deliberately included to ensure that unjust and not simply unlawful acts were covered. ${ }^{160}$ Subsequently, the Human Rights Committee (HRC) concluded that the term arbitrary 'must be interpreted more broadly to include elements of inappropriateness, injustice and a lack of predictability' ${ }^{161}$ To that list, as Nowak suggests, might be added capriciousness and disproportionality. ${ }^{162}$ The much cited decision of the HRC in Hugo van Alphen v The Netherlands provides a good illustration of the principle in action. In Alphen the author was arrested on suspicion of forgery. He was remanded in custody for nine weeks. The author alleged that his

157 See http://news.bbc.co.uk/1/hi/uk_politics/4291388.stm. Had Mr Wolfgang taken proceedings against this prima facie unlawful use of the ss. 44 and 45 power, then its scope may have been appropriately determined. On Padfield grounds the use of the power in such a manner was surely unlawful? The discretionary powers in the TA must be exercised in accordance with the policy and object of the Act, namely the suppression of terrorism. Padfield v Ministry of Agriculture, Food and Fisheries [1968] AC 997, 1030 per Lord Reid.

158 The term 'arbitrary' appears in both the UN Declaration and the ICCPR. See P. Hassan, 'ICCPR: Background and Perspective on Article 9(1)' (1973) 3 Denver Journal of International Law and Policy 153 at 181.

159 UN Doc E/Cn4/826/Rev1 (1964) para. 27. See R. Brody, ‘The United Nations Creates a Working Group on Arbitrary Detention' (1991) 85 American Journal of International Law 709, 712-13.

160 See Hassan, above n. 157 at 173-83. For judicial confirmation see Hammond J in Manga v Attorney General (2002) 2 NZLR 65 at para. 40.

161 See General Comment 8, adopted on 19 May 1989 (CCPR/C/21 Rev 1). Discussed by the HRC in Van Alphen v Netherlands, views adopted on 23 July 1990, Communication 305/1988.

162 M. Nowak, UN Covenant on Civil and Political Rights (OUP: Oxford, 1993) 178. 
arrest and his detention were intended solely to place pressure upon him to waive his absolute right to legal professional privilege and to make incriminating statements. The HRC held that the ICCPR required more than the author's treatment being authorized by law. His treatment needed to be reasonable in the circumstances. Any remand to custody had to be necessary, which in the author's case it was not. In fact it was arbitrary. Similarly, in A v Australia the author of the complaint had been detained for a period of four years in a detention camp for unlawful migrants. In determining that the detention was arbitrary an examination of both the necessity and proportionality of the detention was necessary.

Before national courts the approach of the HRC was approved by the Privy Council in Fok Lai Ying v Governor in Council, ${ }^{163}$ although without much discussion, and subsequently in more depth by the New Zealand Court of Appeal in $R$ v Goodwin. ${ }^{164}$ In Goodwin the appellant had been convicted of the manslaughter of his infant daughter. During questioning, but while not under arrest, the appellant asked if he could leave the police station. He was told that he was not free to go. In a subsequent interview the appellant confessed. The appeal turned on the admissibility of the confession and thus whether the appellant had in fact been arrested or detained. The statement that the appellant was not free to go induced a belief that he had to remain. He was thus detained for the purposes of s. 22 of the New Zealand Bill of Rights Act 1990. With respect to the question of arbitrary detention Richardson J concluded that 'whether an arrest or detention is arbitrary does not turn on its lawfulness but on the nature and extent of any departure from the substantive and procedural standards involved . . . an arrest or detention is arbitrary if it is capricious, unreasoned, without reasonable cause, if it is made without reference to an adequate determining principle or without following proper procedures'. ${ }^{165}$ The principle of legality requires there to be a criterion or criteria against which executive action must be exercised and can thereafter be independently and impartially reviewed. If a discretionary power is unfettered then there is a clear potential for abuse. In these circumstances it is not enough simply to say that such a permissive power is justified because it assists in the detection and prevention of crime. Those goals can be pursued in a way that does not require a power that represents a dangerous exception to the supremacy of law. ${ }^{166}$

Similarly, the compatibility of a permissive power with Article 8(2) was considered by the European Court of Human Rights in Herczegfalvy v Austria. ${ }^{167}$ The application concerned, in part, the interception and control of Herczegfalvy's correspondence by his legal guardian

163 [1997] HKLRD 810; (1997) 7 HKPLR 327.

164 (1993) 2 NZLR 153.

165 Ibid. at 189.

166 Dedman v The Queen (1985) 2 SCR 200 paras. 24-5, Dickson CJC dissenting.

167 [1993] ECHR 10533/83. 
and the psychiatric hospital where he was detained. Before the European Court of Human Rights the applicant argued that the interception was not authorized by law and could not therefore be justified under Article 8(2). In reply the Austrian state argued that the authority for such interceptions could be found in the Austrian Civil Code and the Hospitals Act. Section 51 of the Hospitals Act stated that a detained patient 'may be subject to restrictions . . . as to their contacts with the outside world'. ${ }^{168}$ However, the law contained no indication of any criteria that should be employed when exercising the power, and any mechanism by which the decision could be reviewed ex post facto. ${ }^{169}$ The European Court of Human Rights held that this lack of precision was incompatible with the requirements of Article 8(2). The Court concluded that if a law confers a discretion on a public authority it must indicate the scope of the discretion' ${ }^{170}$ Moreover, in the absence 'of any details at all as to the kind of restrictions permitted or their purpose, duration and extent or the arrangements of their review ... the provisions do not offer the minimum degree of protection against arbitrariness required by the rule of law in a democratic society'. ${ }^{171}$

The principle of legality thus has two important aspects, one preventative and one remedial. First, a discretion that has the potential to interfere with Convention rights should not be so permissive that it allows arbitrary interferences with rights to shelter behind it. Generally, a law that 'confers a discretion must indicate the scope of that discretion'. ${ }^{172}$ This is not the 'impractical and unworkable prescription' that Lord Steyn thought it was. ${ }^{173}$ Where the legislature 'has given a plenary discretion to do whatever seems best in a wide set of circumstances [then] there is no "limit prescribed by law"', ${ }^{174}$ for where there are "no standards governing the exercise of the discretion granted by the [law] the scheme permits and encourages an arbitrary and discriminatory enforcement of the law' ${ }^{\prime}{ }^{175}$ Permissive powers invite manipulation. They can be used for purposes for which they were not granted, as ss. 44 and 45 of the TA demonstrate. While the legislature might mandate their use for a specific purpose, operationally because the power is expressed in permissive terms it can be used for a range of other purposes. Such permissive powers facilitate the sotto voce infringements of Convention rights in a manner that defeats the very purpose of the Convention. For example, ss. 44 and 45 have been

168 Ibid. at para. 269.

169 In fact it was not clear from the text of the law who exactly was empowered to make the decision.

170 Above n.166 at para. 89.

171 Ibid. at para. 96.

172 Silver v United Kingdom [1981] ECHR 5947/72 at para. 88.

$173 R(S) \vee$ Chief Constable of South Yorkshire [2004] UKHL 39 at para. 36, per Lord Steyn.

174 Irwin Toy v Quebec [1989] 1 SCR 92 at para. 64.

175 Papachristou v City of Jackonsville 405 US 156 at 170 (1972). 
misused for public order purposes. ${ }^{176}$ Moreover, such powers deny equality before the law. As they have no standard they can in effect give free reign to the personal stereotypes or prejudices of the individual officer in their application. ${ }^{177}$ Thus, a discretion must be controlled by some objective criterion or criteria. As the US Supreme Court noted in Brown v Texas when 'a stop is not based on objective criteria the risk of arbitrary and abusive police practices exceeds tolerable limits'. ${ }^{178}$ There needs to be a controlling criterion that guarantees 'that an individual's reasonable expectation to privacy is not subject to arbitrary invasions solely at the unfettered discretion of the officers in the field'. ${ }^{179}$ As White J observed the requirement of reasonableness as a control on law enforcement searches was required by the Constitution in order that the privacy and security interests of the individual were not arbitrarily invaded. ${ }^{180}$ The requirement of reasonableness represents a means of reconciling the competing interests of the individual's privacy and security from arbitrary interferences on the one hand and the government's interests in the detection and prevention of crime on the other. ${ }^{181}$ In cases where the legislature has departed from the reasonableness standard, then there must be some mechanism containing an objective standard that ensures that the individual's privacy and security interests are not left at the whim of the official exercising a standardless power. As the French Conseil constitutionnel observed, 'the performance of checks entrusted by the law to the criminal investigation police must be based on purely objective criteria, to the exclusion of all forms of discrimination prohibited by the Constitution' ${ }^{182}$ Similarly, in $R e$ Ontario Film and Video Appreciation Society the Ontario Board of Censors enjoyed a broad statutory power to censor films. There were, however, no standards constraining the exercise of the censorship discretion under the Theatres Act or any of the regulations made under the authority of the Act. The Ontario Supreme Court held that:

The Charter requires reasonable limits that are prescribed by law; it is not enough to authorize a board to censor or prohibit the exhibition of any film of which it disapproves. That kind of authority is not legal, for it depends on the discretion of an administrative tribunal. However dedicated, competent and well-meaning the board may be, that kind of regulation cannot be considered as 'law'. It is accepted that law cannot be vague, undefined, and totally discretionary; it must be ascertainable

176 M. Berlins, 'When a slogan equals terrorism' The Guardian (3 October 2005); see http://politics.guardian.co.uk/homeaffairs/story/0,11026,1583685,00.html. 'Heckler, 82, who dared called Straw a liar is held under terrorist law', Daily Telegraph (30 September 2005); see http://www.telegraph.co.uk/news/main.jhtml?xml = /news/ 2005/09/29/nlab29.xml.

177 Papachristou v City of Jacksonville 405 US 156 at 171 (1972).

178443 US 52 (1979).

179 Ibid. at 56.

180 Ibid. at 53.

181 Terry v Ohio 392 US 1 (1968), 20-21 per Warren CJ.

182 Conseil constitutionnel Decision 93-325, 13 August 1993. 
and understandable. Any limits placed on the freedom of expression cannot be left to the whim of an official; such limits must be articulated with some precision or they cannot be considered to be law. ${ }^{183}$

This issue also arose before the South African Constitutional Court in Dawood v Minister of Immigration. ${ }^{184}$ At issue in Dawood was the validity of s. 29(9) of the South African Aliens Control Act. The Act granted immigration officials a discretionary power to exclude foreign spouses from the country while their applications for immigration permits were considered, by refusing to renew or grant a temporary permit in the meantime. The exercise of the discretionary power had the potential to interfere with the constitutional right to dignity that underpinned marriage. The issue for the Constitutional Court was whether an unconstrained discretion could meet the requirement that limits on constitutional rights be 'prescribed by law'. The Court held that a broad discretionary power could not constitute a 'law' for the purposes of s. 36 of the Constitution, the limitation clause. 'It is an important principle of the rule of law that rules be stated in a clear and accessible manner', O'Regan J concluded, for 'if broad discretionary powers contain no express constraints, those who are affected by the exercise of the broad discretionary powers will not know what is relevant to the exercise of those powers or in what circumstances that they are entitled to relief' ${ }^{\prime 85}$ It is not enough simply to say that the power can be exercised in a manner compatible with the Constitution or read down into conformity. It is for the legislature to provide guidance on when it is justifiable to limit rights under a discretionary power either in the Act or via delegated legislation. ${ }^{186}$ Without criteria the exercise of the power will introduce an element of arbitrariness that is inconsistent with the constitutional protection of rights. ${ }^{187}$

Second, the presence of an objective standard enables effective ex post facto review and scrutiny that will ensure the lawfulness of any interference with Convention rights and provide a remedy if necessary. Here a court must not be hampered in testing the necessity of limits placed on Convention rights by rules such as the level of scrutiny or the absence of an objective legal standard that provides sufficient means to measure the legality of executive action. A standardless power is a good example of the latter. Decisions made under its authority do not need to be justified under objective criteria. Instead they rest on subjective assessment made by the exercising officer which ex post facto a court is unable to scrutinize effectively in terms of the Convention simply because no standard is required by

183 (1983) 31 OR (2d) 583 at 592 (Ont HC).

184 [2000] CCT 35/99; 2000 (8) BCLR 837. See also I. M. Raufenbach, "The Limitation of Rights' (2001) Journal of South Africa Law 617 at 635.

185 Dawood, above n. 183 at para. 47.

186 Dawood, above n. 183 at para. 53.

187 Dawood, above n. 183 at para. 58. 
the statute. There will inevitably be cases where an individual's Convention rights are infringed and yet he will be unable to obtain an effective remedy. For instance in Smirnov v Russia ${ }^{188}$ the applicant complained about a search of his apartment. The applicant was representing a number of individuals in proceedings although he was not under suspicion himself. The search warrant issued by the Public Prosecutor was broadly drafted granting the police an unrestricted discretion in its execution. ${ }^{189}$ The police were free to seize what they liked, and indeed did so. The European Court of Human Rights held that not only was the search not carried out 'with relevant and sufficient grounds' but there was also an absence of effective safeguards to constrain the exercise of the discretion and to prevent abuse. ${ }^{190}$

\section{Legality and Discrimination}

But perhaps the strongest argument that the safeguards are insufficient is the possibility that the standardless power might easily be employed arbitrarily on the basis of racial prejudice. Any unbridled discretion that has the potential to be employed in an arbitrary manner has implications for the equal application of the law. ${ }^{191}$ Here the Home Office's statistics do not make for very comfortable reading. In a typical year before the $7 / 7$ attacks, ${ }^{192}$ an average of 8,120 stops and searches were conducted by police forces in England and Wales. ${ }^{193}$ In the Metropolitan area, the most ethnically diverse part of the United Kingdom, there were 5,245 stop and searches under ss. 44 and 45, leading to 57 arrests of which 2 were related to terrorism. ${ }^{194}$ Both individuals arrested for terrorism were white. However, over a quarter of those stopped and searched were not white. ${ }^{195}$ Of the 57 arrests for offences other than terrorism, 26 individuals were from ethnic minorities. Indeed from 2001-2005 a black or Asian individual was over four times more likely to be stopped under the TA than a white one. ${ }^{196}$ Not surprisingly since the $7 / 7$ attacks the ss. 44 and 45 power

188 [2005] ECHR 71362/01.

189 Ibid. at para. 48

190 Ibid. at para. 49

$191 R$ v Belnavis [1997] 3 SCR 341 at para. 66, per La Forest J.

192 That is, the suicide bombings of the London transport network that occurred on 7 July 2005.

193 Taking an average of the years between 2000-2005 of the exercise of the TA power in relation to pedestrians. Section 95 reports published before 2005 may be accessed at http://www.homeoffice.govuk/rds/section951.html. From 2006 s. 95 reports are available from the Ministry of Justice: http://www.justice.govuk/docs/ race-and-cjs-stats-2006.pdf.

194 Home Office, Statistics on Race and the Criminal Justice System - 2004 (Home Office: London, 2005) 35, Table 4.8.

1951,443 (27.5 per cent).

196 The European Court of Human Rights held in DH v Czech Republic [2006] ECHR $57325 / 00$ that 'statistics are not by themselves sufficient to disclose a practice which could be classified as discriminatory' at para. 46. While the statistics are no doubt flawed they do nevertheless reveal a pattern that should be cause for concern. There is, of course, further evidence. The PACE Code contemplates such 
has been used more frequently. ${ }^{197}$ During 2005/2006 the annual total of exercises of the TA power nearly doubled. ${ }^{198}$ Moreover, the year 2005/2006 showed a significant increase in the use of the TA power against visible minorities. ${ }^{199}$

This pattern is not surprising. Code A of PACE states that there may be circumstances . . . where it is appropriate for officers to take account of a person's ethnic origin in selecting persons to be stopped in response to a specific ${ }^{200}$ terrorist threat (for example some international terrorist groups are associated with particular ethnic identities) ${ }^{\prime 201}$ In other words, ss. 44 and 45 of the TA when read with the PACE Code allow an officer to engage in racial profiling. ${ }^{202}$ There are, Swiney suggests, ${ }^{203}$ two definitions of racial profiling. Under the narrow one racial profiling occurs when race is used as the sole criterion for determining whom to stop and search. This is the definition favoured by the House of Lords in Gillan. The second broader definition occurs when race is or ethnicity is one factor that is taken into account amongst others. Indeed, race can influence decisions subconsciously. This broader definition is favoured by the US Department of Justice. ${ }^{204}$

The over-use of police powers against minority communities is, of course, nothing new and since the Lawrence Inquiry purportedly is a

discrimination. And government ministers have made statements that certain communities should expect to be singled out; see The Guardian (2 March 2005) quoting Hazel Blears MP, then Minister of State at the Home Office. See also House of Commons Home Affairs Committee, Terrorism and the Community Relations, Sixth Report of Session 2004-2005 HC-165 III (HMSO: London, 2005) Ev. 98-99.

197 In fact between 2001-2005 there were 24,781 incidents when the TA power was used against pedestrians. In 2005-2006 there were 19,064.

198 In 2004/2005 there were 10,941 stops and searches of pedestrians using the TA power. In 2005/2006 there were 19,064. Statistics on Race and the Criminal Justice System - 2005 (Home Office: London, 2006) 34, Table 4.8. Statistics on Race and the Criminal Justice System - 2006 (Ministry of Justice: London, 2007) 36, Table 4.8 .

199 2005/2006 (percentages): White 61; Black 11; Asian 21; Other 6. 2004/2005 (percentages): White 74; Black 6; Asian 11; Other 5. Source: Statistics on Race . . 2005, above n. 197 at 34, Table 4.8. Statistics on Race . . 2006, above n. 197 at 36, Table 4.8. Interestingly the figures for $2002 / 2003$ are similar to those in 2006, a legacy no doubt of the 9/11 attacks; Statistics on Race and the Criminal Justice System - 2003 (Home Office: London, 2004) 41.

200 Presumably specific in this context means just that and not some vague generalized threat.

201 PACE Code A, para. 2.25.

202 S. Choudry and K. Roach, 'Racial and Ethnic Profiling' (2003) 41 Osgoode Hall LJ 1 at8.

203 C. F. Swiney, 'Racial Profiling of Arabs and Muslims in the US: Historical, Empirical, and Legal Analysis Applied to the War on Terrorism', (2006) 3 Muslim World Journal of Human Rights 1 at 7-8. See also D. Ramirez et al., 'Defining Racial Profiling in a Post 9/11 World' (2003) 40 American Criminal Law Rev 1195 at 1206 where it is argued that 'racial profiling exists where race or nationality is used as a factor in determining whom to stop based on the belief that race, ethnicity or national origin are possibly correlated with criminality'.

204 See Swiney, above n. 202 at 7. 
matter of great concern. ${ }^{205}$ Such communities have been subject to arbitrary powers of stop and search before. ${ }^{206}$ In many ways ss. 44 and 45 are similar to the 'sus' laws that were repealed when empirical evidence demonstrated their over-use against certain minority communities. ${ }^{207}$ Where a stop is based solely on race it will be discriminatory. ${ }^{208}$ As McIntyre J observed, 'distinctions based on personal characteristics attributed to an individual solely on the basis of association with a group will rarely escape the charge of discrimination'. ${ }^{209}$ In United States v Brignoni-Ponce the US Supreme Court held that a stop made by a border patrol solely on the basis of racial appearance was unconstitutional. While Mexican appearance could be a relevant factor it did not on its own justify stopping individuals. ${ }^{210}$ Racial discrimination, as the European Court of Human Rights noted in Timishev v Russia, ${ }^{211}$ is 'a particularly invidious kind of discrimination and in light of its perilous consequences requires from the authorities special vigilance and vigorous reaction'. The Council of Europe urges contracting states to ensure that the principle of nondiscrimination is applied in the context of policing and, when dealing with emergencies, the Council urges respect for the rule of law, and an absence of discrimination coupled with adequate safeguards. ${ }^{212}$

'There is no more effective practical guaranty against arbitrary and unreasonable government', concluded Jackson J, 'than to require that the principles of law which officials would impose upon a minority must be imposed generally . . . conversely, nothing opens the door to arbitrary action so effectively as to allow those officials to pick and choose only a few to whom they will apply legislation, and thus to escape the political retribution that might be visited upon them if larger numbers were affected' ${ }^{213}$ We might therefore have expected a robust judicial response in Gillan to what appears to be a pattern of

205 Sir William MacPherson of Cluny, The Stephen Lawrence Inquiry, CM 4262-1, 1999) 6.

206 See e.g. C. F. Willis, 'The Use, Effectiveness and Impact of Police Stop and Search Powers', Home Office Research and Planning Unit Paper 15 (1983). At 22 Willis concludes 'Blacks and particularly young black males, are much more likely to be stopped and searched by the police than whites'.

207 Home Affairs Committee 1979-80, Race Relations and the 'Sus' Law, HC 559 (21 April 1980).

208 And on the authority of the Roma Rights case discriminatory, above n. 52. See also Adulaziz, Cabales and Balkandali v United Kingdom (1985) 7 EHRR 471.

209 Andrews v Law Society of British Columbia [1989] 1 SCR 143 at 174-5.

210422 US 873 at 886-7 (1975). See also United States v Avery 137 F 3d 343 (6th cir, 1997). However, see United States v Martinez-Fuerte 428 US 543 at 563 (1976) where the US Supreme Court permitted stops that were based largely on racial appearance at fixed border checkpoints as opposed to roving stops by patrols. See also United States v Bowen 500 F 2D 960 at 965 (9th Cir, 1974).

211 [2006] ECHR 55762/00 and 55974/00 at para. 207.

212 The Fight against Terrorism - Council of Europe Standards, 2nd edn (Council of Europe Publishing: Strasbourg, 2004) Principle 11.

213 Railways Express Agency v New York 336 US 106 at 466-7 (1949). 
discriminatory stops and searches. ${ }^{214}$ Article 14 is after all an important weapon in preventing the development of patterns of discrimination within society. Article 14 is intended to shield individuals from objectification based on stereotypes, particularly those who have suffered such stereotyping in the past. ${ }^{215}$ Profiling has a pernicious effect in practice. It encourages people to deal with persons from different races as 'black', 'white', 'Asian' and so on, rather than individuals worthy of equal concern and respect. ${ }^{216}$ However, because of the standardless sweep of the power in ss. 44 and 45 there is a danger that it might act as a mechanism for giving effect to crude stereotyping. Those who possess the crude proxy characteristic, namely certain racial origins, are taken to possess the material characteristic. The proxy is based on a crude sociological generalization for which there is little evidence, and creates an atmosphere where crude pejorative stereotypes will be employed either consciously or unconsciously. ${ }^{217}$ Of course, discrimination on the basis of race cannot be justified on utilitarian grounds. ${ }^{218}$ Everyone is entitled to be treated as an individual and not as a statistical unit. ${ }^{219}$ On the facts the Roma Rights case would be good authority for arguing that the current practice of stop and search under ss. 44 and 45 is directly discriminatory being inherently and systematically discriminatory on racial grounds'. ${ }^{220}$

However, in Gillan Lord Brown was able to distinguish the Roma Rights case on the grounds that an individual's ethnic profile was not the sole factor in determining whether to stop and search under ss. 44 and 45. Racial origins were simply part of an overall profile. ${ }^{221}$ The police would need to have regard to other factors when deciding to stop and search under the authority of ss. 44 and 45 . In other words there was no intentional discriminatory use of the power in a racially motivated manner. Thus the House of Lords saw little difficulty in employing race as in effect a key element of a terrorist profile, although some members of the Appellate Committee were clearly troubled by the manifest discrimination. Lord Brown concluded that it was inevitable that so long as the principal threat [is from al Qaeda] ... a disproportionate number of those stopped and searched under

214 Ghaidan v Godin-Mendoza [2004] 2 AC 557 at para. 19, per Lord Walker. See also C. R. Sunstein, 'Fear and Liberty' (2004) 71 Social Research 1 at 20-2.

215 Miron v Trudel (1995) 29 CRR (2D) 189 at 207-8. Andrews v Law Society of British Columbia (1989) 56 DLR 1 at 34, per Wilson J.

216 M. Perry, 'Disproportionate Impact Theory' (1977) 125 U Penn LR 540 at 550.

217 Arguably 'institutional racism' is a manifestation of unconscious racism.

$218 R$ (Carson) v Secretary of State for Work and Pensions [2005] UKHL 37, [2006] 1 AC 173, per Lord Hoffmann. His lordship's remarks were directed at discrimination on the basis of sex rather than race, but are equally applicable in the latter context. Discriminatory treatment on prohibited grounds 'offends the notion that everyone is entitled to be treated as an individual and not a statistical unit'. 
s. 44 TA will be of Asian appearance'.222 To many, no doubt, Lord Brown's statement appears to be an incontrovertible fact. For instance, all but one of the $7 / 7$ bombers were British Asians. However, simply because one set of terrorists fits the profile it does not mean that future ones will. The key question here, surely, is are we simply succumbing to the temptation to fall into pejorative stereotyping? Indeed, how strong is the correlation between the proxy trait, namely race, and the material one, that is a propensity to commit terrorist crime? It might be argued that as profiling potential offenders is a well-established law enforcement practice it should be used in this context; after all profiling is seen by many as a reliable and effective investigatory tool. ${ }^{223}$ But the key question in this context is how rational is profiling? By focusing on race we are ignoring an important fact, namely that Islamic terrorism is driven by a fundamentalist interpretation of a religion. This form of terror is not linked exclusively to a particular ethnicity in the same way, for example, as Irish terrorism was. $^{224}$ The traditional paradigm of viewing terrorism as connected to territorial disputes is not appropriate post 9/11. ${ }^{225}$ Moreover the alQaeda network is simply not a terrorist group like the IRA. For instance, while some of Bin Laden's aims might have a territorial element to them, the Islamist groups that form the al-Qaeda network are not committed to the liberation of an ethnic homeland from an occupier. The motivation is of a different order, springing from a divine injunction to defend one's religion from its enemies. Islamic terrorists will inevitably be a heterogeneous group of nationalities and ethnicities, as the patchy records of those trained in al-Qaeda's Afghan camps reveal. In contrast to Irish republican terrorism, for instance, where the majority of operatives were Irish or of Irish descent, Islamist terrorists could literally be anyone. Ethnic targeting will therefore only ever be limited in effect. It is not uncommon for white, mixed race and black individuals to convert to Islam. Some will inevitably become Salafists or Islamists. ${ }^{226}$ During the civil war in Yugoslavia a significant number of Bosnian mujahideen were not

222 Ibid. at para. 80.

223 D. Tanovich, 'Using the Charter to Stop Racial Profiling' (2002) 40 Osgoode Hall LJ 145 at $157-8$.

224 A recent internal review by the government concluded that it is difficult to generalise about the profile of young British Muslims who are attracted to Islamist terrorist activity either in the UK or overseas': UK Foreign and Commonwealth Office/Home Office, Draft Report on Young Muslims and Extremism. (April 2004). Available online at http://www.globalsecurity.org/ security/library/report/2004/muslimext-uk.htm.

225 There may of course be a coincidence between the two, as in Kashmir. But Islamic terrorists do not subscribe to notions of states and sovereignty for the simple reason they believe that the world belongs not to men but God.

226 Broadly speaking Salafists are Muslims who believe that society should be ordered as it was in the time of Mohammed, in accordance with the Qur'an and hadith (the record of the words and deeds of Mohammed). Islamists are a similar group in that they too hope to establish a purely Islamic society. However, 
Arab-Afghans but recruits from the West including converts. ${ }^{227}$ Such a convert was of course Richard Reid, the so-called 'shoe bomber' who attempted to commit mass murder by blowing up a transAtlantic flight with an explosive device concealed in his shoes. Reid is of mixed race being of British and Jamaican descent. ${ }^{228}$ Similarly in November 2005 a white, former Christian, middle-class Belgian national, Muriel Degauque, ${ }^{229}$ took part in a suicide attack against US forces in Baghdad killing six others in the process. In fact there is growing evidence that the suicide bombers who attack cities such as London in the future will not be Asian in appearance but white. The presence in the alleged August 2006 conspirators of white converts should not be a surprise to anyone. Faced with an organized offensive against it al-Qaeda has simply adapted its tactics. In 2005 The Global Media Front, a recognized mouthpiece of al-Qaeda, published a document on the Internet indicating that al-Qaeda intended to use white converts to undertake attacks. Al-Qaeda refers to such people as 'Rakan Bin Williams'. The site went on to place the use of such converts in the context of al-Qaeda's strategy of surprise and adaptation: 'They restricted the Arab and were attacked by those from Pakistan . . . you will not be able to find any solution because our next soldier cannot be put under surveillance or restricted in his movements or arrested' ${ }^{230}$ No doubt for this very reason the recruitment of white westerners has become an attractive tactic for al-Qaeda. The possibility of this threat has been recognized by the government. In an interim government report, Young Muslims and Extremism, the authors noted that whilst many Muslims have grown up in Muslim households, a significant number come from liberal, non-religious Muslim backgrounds, or only converted to Islam in adulthood . . . these converts include white British nationals and those of West Indian extraction'. ${ }^{231}$ Arguably white recruits are more often susceptible to the jhadi message. Converts to Islam lack the Arabic language skills so necessary to be able to read the Koran properly, ${ }^{232}$ and thus are open

Islamists may seek to co-opt the institutions of the modern state to achieve their ends, something that a Salafist would reject. A useful discussion of the various Islamic groupings can be found in Jason Burke, al-Qaeda (London: Penguin, 2004) 40.

227 E. F. Kohlmann, al-Qadea's Jihad in Europe (Berg: Oxford, 2004$) 95$.

228 See http://news.bbc.co.uk/1/hi/uk/1731568.stm.

229 See http://www.timesonline.co.uk/article/0,,2092-1902761,00.html.

230 M. al-Shishani, 'Westerners Being Recruited by al-Qadea' (2005) 2 Terrorism Focus 23; http://www.jamestown.org/terrorism/news/ article.php? articleid $=2369849$.

231 It is difficult to generalize about the profile of young British Muslims who are attracted to Islamist terrorist activity either in the UK or overseas. Backgrounds and motivation to undertake terrorist or related activity vary. They range from foreign nationals now naturalized and resident in the UK arriving mainly from North Africa and the Middle East, to second and third generation British citizens whose forebears mainly originate from Pakistan or Kashmir.

232 The Koran, being the word of God, must be studied in its seventh century classical Arabic to be read correctly. 
to unquestioning adoptions of more extreme interpretations of the various Sura (chapters). Moreover, without a network of Muslim friends and family who can offer a different interpretation of Islam, they are left with the version offered by their recruiters. ${ }^{233}$ For alQaeda groups the attraction is obvious. White recruits are better able to practise taqiyya ${ }^{234}$ and blend seamlessly into what is after all their own society. It would be a rare lucky break indeed if ss. 44 and 45 intercepted such a person, as Lord Carlile observes. ${ }^{235}$ But then stop and search in general has rarely been an effective means of apprehending offenders. ${ }^{236}$

Moreover, the irrationality of using race as a proxy trait is a good example of probability neglect. Not surprisingly we are gripped by a degree of fear when we think about terrorism. In such circumstances we naturally tend to focus our thoughts on the adverse outcomes while ignoring the likelihood of their occurrence. Such neglect of probability 'can produce significant problems for law and regulation'. ${ }^{237}$ The majority of us have no idea how probable it is that we will be injured or killed in a terrorist incident. In the absence of this information we rely on our own perceptions. How easy is it for us to recall or visualize a salient example of the event in question? Images of terrorism are readily available. One can quite easily recall the images of the aircraft hitting the World Trade Centre in New York or the exploded bus in Tavistock Square in London. Terrorists of course realize this for, as Sunstein observes, such people (whether they know it or not) 'show a good understanding of the availability heuristic simply because a highly publicised terrorist attack ${ }^{238}$ is likely to create more fear than base statistics warrant'. ${ }^{239}$ Although we are far more likely to die in a car crash or from chronic illness we tend to perceive

233 P. Sookhdeo, Understanding Islamic Terrorism (Issac Publishing: Pewsey, 2004) 178.

234 The practice of disguising one's beliefs or intentions while remaining true to Islam.

235 Lord Carlile of Berriew QC, Report on the Operation in 2004 of the Terrorism Act 2000 (HMSO: London, 2005) para. 115.

236 J. Lea, 'The MacPherson Report and the Question of Institutional Racism' (2000) 39 Howard Journal 219 at 230. J. Millar et al., 'The Impact of Stops and Searches on Crime and the Community', Home Office Police Research Series 127 (2000) 19-27.

237 C. Sunstein, 'Probability Neglect, Emotions, Worst Cases and the Law' (2004) 112 Yale $L J 61$ at 63.

238 See further L. Richardson, What Terrorists Want - Understanding the Terrorist Threat (John Murray: London, 2006). At 101 Richardson observes 'Since the days of the Zealots terrorists have understood the value of publicity . . . no spectacular, however, quite compares with the image of aircraft ramming into the Twin Towers and the subsequent collapse of those bastions of American capitalism'.

239 C. Sunstein, 'Hazardous Heuristics' (2003) 70 Uni Chicago L Rev 751 at 762 . The availability heuristic is a cognitive bias that causes people to base their future prediction of events on the ease with which salient examples come to mind. Events that are vivid and shocking create a stronger emotional impact, and are thus recalled with greater ease. However, such events might be statistically improbable or infrequent. In other words events that are more available are more likely to be judged as probable. See A. Tversky and D. Kahneman, 'Availability: A 
terrorism as a more pressing threat to ourselves and society, and in light of this it is easier to justify extraordinary measures to deal with it. We allow our strong emotions, principally fear, to drive out qualitative judgments, ${ }^{240}$ and spend a disproportionate amount of time planning for worst-case scenarios. Thus we tend to focus on high risk information believing it to be more compelling and accurate, and plan our response accordingly. For instance in the wake of 9/11 in the United Kingdom the government conducted exercises based on scenarios involving the use of biological and nuclear weapons. ${ }^{241}$ In September 2003 the government undertook Exercise Osiris II at London's Bank Underground station simulating a chemical attack. However, when the much anticipated attack came on 7 July 2005 it was conducted by a small cadre of bedsit fanatics wielding devices manufactured from household chemicals. ${ }^{242}$ In such a climate it is inevitable that representative institutions will neglect probability too. In fact 'a good deal of legislation and regulation can be explained partly by reference to probability neglect when emotions are running high'. ${ }^{243}$ The legislative response to terrorism carries with it a severe risk of probability neglect. ${ }^{244}$ Sensationalist saturation media coverage of terrorism hardly helps, triggering the availability heuristic. ${ }^{245}$ Overreaction is inevitable, with broad sweeping and largely ineffective emergency powers being the result. Sections 44 and 45 of the TA are a good example.

Furthermore, the discriminatory effect of the operation of ss. 44 and 45 of the TA is also counterproductive. ${ }^{246}$ If society as a whole is to reduce the risk of Islamist terrorism then moderate Muslims need to be supported. However, the over-use of emergency powers creates a danger that Muslims will be stereotyped and alienated. In the end, faced with what is perceived to be a partial and aggressive use of police powers, there is a danger that the Muslim community will feel stigmatized, and become increasingly angry and alienated. In such

Heuristic for Judging Frequency and Probability' (1973) 5 Cognitive Psychology 207 at 208. See also D. Kahneman,P. Slovic, and A.Tversky, Judgment under Uncertainty: Heuristics and Biases (Cambridge University Press: Cambridge, 1982).

240 See Sunstein, above n. 234 at 70.

241 Full details of Exercise Osiris and its outcome can be found on the UK Resilience website: http://www.ukresilience.info/preparedness/exercises/londoncasestudies/ osiris.aspx.

242 Report of the Official Account of the Bombings in London on 7th July 2005 (HMSO, HC 1087), paras. 7-13 and 59-60. With worst-case scenarios we assume that planning for these eventualities is sufficient for all such events. In fact by focusing on the worst case we divert resources and attention away from less available but more probable events thus making them more likely.

243 Sunstein, above n. 234 at $97-8$.

244 Sunstein, above n. 234 at 100.

245 An intense emotional reaction to a very low probability event. See A. Tversky, . \& D. Kahnemann, 'Judgments of and by representativeness' in Kahneman et al., Judgment under uncertainty, above n. 236 at 84-100.

246 Equally, ss. 44 and 45 do not encourage intelligence-led policing but instead encourage the police to rely on physical appearance. 
circumstances it is probable that we will lose the support of the very community we need to tackle this problem effectively. ${ }^{247}$ Individuals who see the police and criminal justice system as unfair are unlikely to assist the police by informing on suspicious activity or indeed testifying. ${ }^{248}$ Arguably, in the long term such crude powers can hinder law enforcement by undermining the legitimacy of the police. Disillusioned young men are of course the very people that terrorists seek to recruit, especially at a time where the concept of Islamic Umma has attained greater potency in general, and for some the bonds of Tawheed are strengthening. ${ }^{249}$ Moreover, in the post-Lawrence world the use of such powers in a discriminatory manner does nothing to improve relations between the police and other minority communities who are not seen directly as the source of the threat. For ordinary people police legitimacy is driven more by their perceptions of procedural fairness than by instrumentalities such as their effectiveness in fighting crime. ${ }^{250}$ The legitimacy of the police is, in the public's mind, linked to judgments on the fairness with which the police make decisions and exercise their authority. Indeed, unequal treatment is a major source of dissatisfaction. ${ }^{251}$ Regardless of their ethnicity 'people cooperate with the police when they view the police as legitimate' ${ }^{252}$ Unfairness or perceived unfairness will lead to alienation, defiance and non-cooperation. ${ }^{253}$ Somewhat depressingly we have been here before. In 1983 a Home Office research paper concluded that the repeated use of stop and search powers can have an adverse effect on police/community relations to the point where any contact with the police comes to be seen as . . . a sign of official hostility'. ${ }^{254}$ The report went on to conclude that 'without a secure base of community support the use of powers of this kind, however extensive or circumscribed, rapidly becomes burdensome and ineffective' ${ }^{255}$ Indeed, this has been a persistent concern of both inquiries and researchers in the intervening 25 years. ${ }^{256}$ Moreover, the perception of a fundamentally

247 See e.g.T. Ghaffur, 'The Impact of Culture, Customs and Race in Contemporary Policing' 7 August 2006 NBPA Conference. Available from http://www.nbpa. co.uk/.

248 S. J. Ellman, 'Racial Profiling and Terrorism' (2003) 22 NY Law School Journal of Human Rights 305 at 335.

249 The Umma are the community of the faithful. Tawheed is, in essence, the core tennets of Islam.

250 Jason Sunshine, "The Role of Procedural Justice and Legitimacy in Shaping Support for Policing' (2003) Law and Society Review 513, 524.

251 Ibid. at 516.

252 Ibid. at 537.

$253 \mathrm{Ibid}$. at 519 .

254 See Willis, above n. 205 at 23.

255 Ibid.

256 Sir William MacPherson, above n. 204 at para. 6.45(b): 'Whilst we acknowledge and recognise the complexity of this issue and in particular the other factors which can be prayed in aid to explain the disparities, such as demographic mix, school exclusions, unemployment, and recording procedures, there remains, in our judgment, a clear core conclusion of racist stereotyping'. J. Millar et al., above n. 233 at 47 . Lea, above n. 233 at 228. 
unfair criminal justice system contributes to broader racial divisions in society. ${ }^{257}$ When politicians talk of 'redressing the balance' the costs of such adjustments do not fall evenly across society. As Waldron has pointed out, it is often minority communities that carry the heaviest burden. ${ }^{258}$ Of course, beyond the specific context of terrorism there is the wider question of the role of government in preventing discrimination. Arguably in a free and democratic society government has a special duty not only to ensure that discrimination on prohibited grounds is prevented but also to act as a teacher. Where the government is seen to act in a discriminatory manner it acts in a way that not only undermines its own efforts to prevent such action in private parties, it also acts inconsistently with its own laws and policies intended to eradicate discrimination. Not only are the costs of such action higher and more hidden than in the private sector, ${ }^{259}$ discriminatory action by the government is likely to be observed by the wider population and this will inevitably sow the seeds of distrust if not fear of members of the principally targeted group. In such an atmosphere discrimination will flourish. ${ }^{260}$ In these circumstances we need to be especially sure that emergency powers are both necessary and effective.

However, proving direct racial discrimination would be difficult. It would involve an admission by an officer than he had relied on racial stereotypes in the exercise of his discretionary powers. ${ }^{261}$ But of course, under vague discretionary powers people can be stopped at whim, and where there is no controlling criterion then no reason will need to be given. ${ }^{262}$ Be that as it may, while the exercise of ss. 44 and 45 might not constitute direct discrimination it might nevertheless constitute indirect discrimination. In Jordan v United Kingdom the European Court of Human Rights concluded that 'where a general policy or measure has disproportionately prejudicial effects on a particular group it is not excluded that this may be considered as discrimination notwithstanding that it is not specifically aimed or directed at that group' ${ }^{263}$ The power in ss. 44 and 45 is facially neutral. It does not single out any particular group for differential treatment. ${ }^{264}$ It is silent

257 D. Cole 'Racial Profiling and the Future of the Criminal Law' (1999) 26 Human Rights 2 at 3.

258 Above n.143 at 210

259 N. Lund, 'The Conservative Case against Racial Profiling' (2002-2003) 66 Alb Law Review 329, 329-331.

260 There is considerable evidence that intolerance and prejudice are primarily a function of threat perception; see Christina Wells, 'Fear and Loathing in Constitutional Decision Making', (2005) Wisconsin Law Review 115, 158 and 163-8.

$261 R$ v Brown (2003) 64 OR (3d) 161 at 254.

$262 R$ v Ladoucour [1990] 1 SCR 1257, per Justice Sopinka. See also the judgment of Tarnopolosky JA in the Ontario Court of Appeal in the same case ( $R \mathrm{v}$ Ladoucour (1987) 59 OR (2d) 688).

263 Jordan v United Kingdom [1999] ECHR 27746/94 at para. 154.

264 Leaving aside for the sake of argument the impact of PACE Code A. 
as to whom it should be applied. However, indirect discrimination is intended to deal with discrimination that hides behind neutral criteria. Although the law in its form is non-discriminatory it is nevertheless discriminatory in its operation as the burden of its operation falls more heavily on members of discrete and insular minorities. In other words, under ss. 44 and 45 there is a differential impact on members of protected groups. Stops and searches are not intentionally discriminatory. The police intend to intercept terrorists preparing to commit crimes or to gather intelligence. However, in effect the operation of the power is to single out specific groups for special treatment. As the statistics make clear, the operation of ss. 44 and 45 is a paradigm case of indirect discrimination, for the powers when applied interfere with the Convention rights of a higher number of members of racial minorities than whites. In effect it is discriminatory. The European Court of Human Rights has cautioned against simply relying upon statistical analysis as sufficient to prove a prima facie case of discrimination. ${ }^{265}$ However where 'undisputed official statistics' reveal indirect discrimination then this is sufficient proof. ${ }^{266}$

Once a prima facie case of indirect discrimination is made out by a claimant, then the burden of proof shifts to the defendant to demonstrate that there has been no discrimination, and if there has, that it can be objectively justified. ${ }^{267}$ For ss. 44 and 45 to be objectively justified within the terms of the Convention they will need to pursue a legitimate aim in a proportionate manner. ${ }^{268}$ However, there is an immediate problem here. There is no express legal authority for such profiling. A similar situation arose in the South African case City Council of Pretoria $\mathrm{v}$ Walker. ${ }^{269}$ Here the Council differentiated between categories on the basis of race by charging, in a different manner, residents of different suburbs. The effect was to discriminate indirectly against the residents of predominantly white suburbs. The Constitutional Court held that the decision of the Council to establish such a charging regime was not authorized by law, either expressly or by necessary implication. Therefore, the Council's policy was not authorized by law and it could not seek to justify its policy. ${ }^{270}$ Arguably, it is the case that profiling under the TA is not authorized by law and is thus unlawful.

265 Jordan v United Kingdom [1999] ECHR 27746/94 at para. 154.

266 Hoogendijk v The Netherlands [2005] ECHR 58641/00 (dec.) at 21-2. D.H. v The Czech Republic [2007] ECHR 57325/00 at para. 180.

267 Timishev v Russia [2005] ECHR 55762/00 at para. 57.

268 Abdulaziz, Cabales and Balkandali v United Kingdom [1985] ECHR 9214/80 at para. 72. In this context there is clearly some overlap between the first limb of the Daly test that 'the legislative objective is sufficiently important to justify limiting a fundamental right' and the requirement that a measure pursue a legitimate aim. See further Lord Steyn in Daly [2001] UKHL 26 at para. 27.

269 (CCT8/97) 1998 (3) BCLR 257.

270 Ibid. at para. 82. 
Leaving the issue of legality to one side, few would seriously doubt that the prevention and detection of terrorism is a legitimate aim. Although the ss. 44 and 45 power was originally enacted in 1996 as an expeditious response to what is now an historic threat, it has now become an important weapon in counterterrorist policing post 9/11. There can be no doubt of the threat posed by contemporary terrorism. Given the brutal and bloody nature of terrorism the adoption of an effective approach to counterterror policing that is preventative is both highly desirable and wholly understandable.

If we accept that some form of special powers are thus essential to deal with this terrorist threat, the question then becomes, which ones are likely to be effective? In other words, is there a rational connection between the legitimate aim and the legislative means chosen to meet it? Sections 44 and 45, we are told, are an important part of the counterterrorist arsenal. For example, ACPO claims that ss. 44 and 45 are an invaluable tool because they deter and disrupt terrorists, particularly their reconnaissance of potential targets. ${ }^{271}$ Indeed, the House of Lords was itself impressed by similar witness statements to that end. The ss. 44 and 45 powers remained necessary to disrupt terrorist activity and to gather intelligence. ${ }^{272}$ Lord Bingham thus felt able to conclude that, in light of the statement, there was 'no evidence of any kind to contradict or undermine this testimony'. ${ }^{273}$ In doing so Lord Bingham followed a long line of authority in English law whereby the judiciary adopt a highly deferential attitude in cases involving national security and effectively accept the ipse dixit of the executive. However, the Home Office's own statistics tell a different story. In fact a thorough examination of the statistics brings into question the issue of whether the power is effective, and thus necessary. For example, between 2001-2005 there were 24,781 stops and searches under the power. These stops resulted in 364 arrests for offences other than those connected with terrorism, and just 36 for those related to terrorism. Unfortunately, we do not know how many of the 36 arrests for terrorism resulted in a conviction for such offences. As has already been noted, since the $7 / 7$ attacks the TA power has been used more frequently. Consequently the number of arrests has risen. In 2005/2006, 19,064 exercises of the TA power resulted in 59 arrests for terrorist related offences. This 0.3 per cent success rate represented an improvement on the previous combined average of 0.14 per cent. ${ }^{274}$ Nevertheless, this success rate can hardly be said to represent a power that is so effective that it can be described as necessary. Such a low success rate is not surprising given the difficulty in combating contemporary terrorism, where the protagonists

271 Memo to House of Commons Home Affairs Commitee, Terrorism and Community Relations HC 165-II - Evidence.

272 Gillan [2006] UKHL 12 at para. 17 (statement of Catherine Byrne).

273 Ibid.

274 Above nn. 196 and 198. 
are indistinguishable from their law-abiding compatriots. The inescapable conclusion must be that the power in the TA is largely a symbolic one given its limited impact on improving security. Be that as it may, it is tempting to conclude that had there been an instance where ss. 44 and 45 have succeeded in foiling an attack it would have been referred to. In the absence of specific evidence the suspicion must be, that as with ordinary powers of stop and search under PACE, the impact of stop and search in disrupting and deterring terrorist crime is limited. ${ }^{275}$ Instead, as with PACE, the TA powers are in large part directed at controlling disorderly and dangerous groups rather than actually detecting crime. ${ }^{276}$ In this context race is used as a trigger for surveillance and control. Moreover, the statistics seem to indicate that these provisions are, par excellence, what Thomas calls 'comfort legislation' ${ }^{\prime 27}$ whose benefits are primarily psychological. ${ }^{278}$ The presence of police officers stopping and searching people in public places is no doubt to some people reassuring. But the price for providing such reassurance is the significant expansion of policing and police powers. ${ }^{279}$ Equally, no specific evidence was presented showing how ss. 44 and 45 have yielded usable intelligence. Moreover, there is a further 'strong argument to be made that statesanctioned discriminatory treatment of vulnerable and disadvantaged groups should never be permitted even if it could be defended as rational'. ${ }^{280}$ Not only are there more efficient ways of collecting intelligence, the power is most unlikely to disrupt or prevent terrorist attacks. The correlation between the goal of collecting intelligence and the means chosen to achieve it seems implausible in light of the statistics. ${ }^{281}$

Finally for ss. 44 and 45 to be objectively justified, the means chosen to limit the right should do so no more than is necessary to achieve the objective. In Gillan the limitation was imposed not by the statute but by its application. As we have already seen, a vague, over-broad power has the potential to limit rights and freedoms more than is necessary because the law does not clearly demark or control the limits of the power. Under such a power limits on Convention rights will vary with every application. In such a context the key question is what, if any, safeguards have been put in place to prevent abuse? For instance, what guidance has been issued on the lawful exercise of the power? This is not merely some academic exercise. The potential for

275 See Millar et al., above n. 233 at 19-47.

276 See Lea, above n. 233 at 230.

277 P. Thomas, '9/11: USA and UK' (2003) Fordham Law Journal 1193 at 1198.

278 See Waldron, above n.143 at 209.

279 L. Zedner, 'Securing Liberty in the Face of Terror' (2005) 32 JLS 507 at 517.

280 D. Tanovich, 'Using the Charter to Stop Racial Profiling' (2002) 40 Osgoode Hall LJ 145 at 161.

281 It may however be the case that additional evidence might satisfy the requirements of evaluative rationality. 
abuse of security legislation has a long if somewhat tawdry pedigree' $^{282}$ Indeed, the need for safeguards is probably greater in times of crisis when the temptation is to place the exigencies of security before all else. In the context of the TA clearly Parliament intended that the power be used only in connection with activity related to terrorism. Yet the power has resulted predominantly in arrests for crimes not connected with terrorism. Thus Parliament or the courts should put in place incentives and structures to ensure that discretionary powers are not abused. In fact Parliament did not put in place any effective safeguards to prevent the abuse of this power. Rather than addressing the issue of whether and indeed when racial profiling should be used, thereby surrounding the power with proper safeguards, the PACE codes were amended. According to paragraph 2.25 of PACE Code A such action is justified because certain international terrorist groups are associated with particular ethnic groups. This presumably is what the Code means by an 'objective threat'. The Code is silent on how the threat is to be determined. Instead it is left to the various police forces to how the assessment is to be made. The Metropolitan Police Force has issued Police Standard Operating Procedures to determine how that assessment is to be made. ${ }^{283}$ This is surely significant, for nothing in the TA sanctions racial profiling. Yet the PACE Code contemplates treating different classes of people differently. Arguably, this issue should have been addressed directly by Parliament.

It is nonetheless important to recognize that safeguards are not limited to ensuring that the power is excised in a manner compatible with Convention rights. Ex post facto safeguards have a role to play too. The House of Lords concluded that an action in the county court would provide an effect remedy for an abuse of the power. There are, however, a number of problems with this. First, the power is unlikely to be used against the economically favoured or powerful. It is most likely to be used against the disadvantaged. ${ }^{284}$ Second, the abuse of ss. 44 and 45 is likely to remain largely hidden. The innocent will rarely pursue a claim. Litigation is expensive and time-consuming. Moreover, many of those stopped simply lack faith in the legal system to vindicate their rights. ${ }^{285}$ Third, the traditional remedies of

282 See Waldron, above n. 143 at 203.

283 See e.g. the London Metropolitan Police Force's Search Powers under Sections 44/45 Terrorism Act Standard Operating Procedures at 14; http:/ /www.met.police.uk/foi/pdfs/policies/stop_and_search_s44_tact_2000_sop.pdf.

$284 R$ v Landry [1986] 1 SCR 145 at para. 87, per La Forest J: 'There is another cause for concern in granting such a vague discretion. It is unlikely to be used as much against the economically favoured or powerful as against the disadvantaged. It is interesting that the home in Davis v Russell, supra, was described as lodgings, and those in Eccles v Bourque and the present case were apartments. As Professor Paul Weiler has stated, "abuses of police power will rarely affect respectable members of the middle classes", but will instead "focus on the poor and on marginal, minority groups"'.

285 T. Quigley, 'Brief Investigatory Detentions' (2004) 42 Alberta LR 935 at 947. 
English law in the context of human rights are unlikely to be sufficient to vindicate the remedial requirements of the Convention at Strasbourg. ${ }^{286}$

\section{Conclusion}

In the end the House of Lords found that ss. 44 and 45 were compatible with the Convention. But assuming, for the sake of argument, that the courts had identified a possible incompatibility between the Convention and ss. 44 and 45 of the TA what might have been an appropriate remedial response? Here, for example, a court could scrutinize the power as exercised. Sections 44 and 45 of the TA authorize the lawful stop and search of an individual for the purposes of detecting terrorist related crime. Under ss. 44 and 45 a stop and search for other purposes is unlawful. Although in Gillan itself there was no question of either an unlawful search or bad faith on the part of the police, it is undoubtedly true that the power has been instrumental in far more arrests for non-terrorist related offences than for those contemplated by the TA. The power has also been used in questionable circumstances, as the Wolfgang episode rather publicly demonstrated. But given the structure of ss. 44 and 45 a court simply has no way of knowing what the motivations of an individual officer were. As we have seen there is no objective standard which purports to control the exercise of the power in ss. 44 and 45 . Be that as it may, if a stop and search under ss. 44 and 45 produces evidence of criminality other than that related to terrorism, it is still admissible notwithstanding the fact that power may have been employed unlawfully. ${ }^{287}$ In this situation a court would no doubt follow $R \mathrm{v} K K^{288}$ where evidence procured through infringements of both English law and Convention rights was nevertheless admissible at trial. In England and Wales, unless there is an adverse impact on the fairness of proceedings a trial court will not normally ${ }^{289}$ exclude unlawfully obtained evidence. ${ }^{290}$ The rule is a strict one. In fact it might be argued that in practice the

286 Smith and Grady v United Kingdom [1999] ECHR 33985/96 at paras. 137-9.

287 A similar situation arose in Jeffrey v Black [1978] QB 490. The police arrested a man on suspicion of stealing a sandwich from a pub. Without a warrant or consent the police then searched the accused's bedsit where they discovered cannabis. The magistrate dismissed the charges under the Misuse of Drugs Act 1971 on the basis that the evidence had been gathered unlawfully. On appeal the Divisional Court reversed that decision, and sent the case back to be reheard. Since October 2000 'unlawful' includes, of course, acting in a manner incompatible with Convention rights (HRA, s. 6).

288 [1997] AC 558.

289 This is the normal rule. However, in R v Olden [2007] EWCA Crim 726 the Court of Appeal effectively excluded all the evidence that had been obtained as a consequence of an unlawful arrest. The appellant's conviction was quashed as a consequence. No authority was cited by Dyson LJ for his decision.

290 This general rule is subject to exceptions. For example evidence procured through the use of torture is inadmissible (A v Home Secretary (No. 2) [2005] UKHL 71; [2005] 3 WLR 1249). 
strictness of the exclusionary rule fails to provide adequate protection of Convention rights. Not only is the infrequently exercised judicial discretion to exclude evidence on the basis of unfairness a narrow one, ${ }^{291}$ it has been rightly described as somewhat weak. ${ }^{292}$ In these circumstances it is not unreasonable to argue that in the context of ss. 44 and 45 the exclusionary discretion is unlikely to provide an effective remedy for the infringement of Convention rights. Moreover, given that Convention rights are implicated, a new prophylactic rule is necessary to ensure that such rights are not infringed if possible. ${ }^{293}$ After all, rights enshrined in a constitutional document deserve protection consistent with that status. ${ }^{294}$ In this context, at least, one possible alternative to the exclusionary rule would be an inclusionary rule, similar to the one that Scots law takes with respect to unlawfully obtained evidence. Where unlawfully obtained evidence is led in Scotland there is a presumption in favour of exclusion unless the Crown can convince the court that the irregularity should be excused. ${ }^{295}$ The rule in Lawrie v Muir allows a court to balance the interests of the citizen to be protected from illegal or irregular invasions of his liberties by the authorities [with the] interests of the state to secure evidence $f$ necessary to enable justice to be done' ${ }^{296}$ In fact a new inclusionary rule would have a number of benefits. First and foremost, such a rule would uphold Convention rights by providing an effective remedy. Second, the rule would provide an incentive against the routine use of the special power, limiting its use to cases where terrorism might be involved. Such a prophylactic rule may help to prevent the ss. 44 and 45 power being unlawfully used on the pretext of a stop and search for terrorist offences. This would undoubtedly help to give effect to the intention of Parliament in expressly limiting the use of the power to terrorism cases. Third, given the difficulty of detecting unlawful exercises of the power, requiring the exercise to be justified before the Crown may lead the evidence

291 A. Choo and S. Nash, Improperly Obtained Evidence in the Commonwealth: Lessons for England and Wales' (2007) 11 EvPro 75 at 78.

292 R. Cross and C. Tapper, Evidence, 11th edn (OUP: Oxford, 2007) 548.

293 In this context by 'prophylactic' I mean preventative safeguards that ensure that constitutional violations do not occur. J. Grano, 'Prophylactic Rules in Criminal Procedure' (1985) 80 NWUL Rev 100 at 105-6. M. Plaxton, 'In Search of Prophylactic Rules' (2005) 50 McGill LJ 127 at 130-2.

294 Mohammed v The State [1999] 2 AC 111 at 123-4 per Lord Steyn.

295 J. Dawson, "The Exclusion of Unlawfully Obtained Evidence: A Comparative Study' (1982) 31 ICLQ 513 at 537-8. P. Duff, 'Admissibility of Improperly Obtained Physical Evidence in the Scottish Criminal Trial: the Search for Principle' (2004) 8 Edin LR 152.

296 Lawrie v Muir [1950] SLT 39 at 39-40 per Lord Justice-General Cooper. A similar balancing test, drawing on Lord Cooper's judgment, has found favour elsewhere. See further Mohammed, above n. 291, and R v Shaheed [2002] 3 LRC 634. Lord Steyn in Mohammed cites (at 123) Lord Hodson in King v The Queen [1969] 1 AC 304 at 315 as authority for the balancing test his Lordship favours. However, the dicta in King are not those of Lord Hodson but rather Lord Cooper in Lawrie whom Lord Hodson was quoting. 
ensures that the evidence has in fact been gathered lawfully. This may go some way in helping to maintain public confidence in the criminal justice process. Conduct that undermines the rule of law is the sort of conduct that a court should not tolerate much less endorse. ${ }^{297}$ And finally, an inclusionary discretion would allow a court adequately to weigh the public interest in prosecuting those suspected of grave crimes. To a large extent a balancing test answers Cardozo's conundrum. ${ }^{298}$

Alternatively, it may be possible for the courts to read ss. 44 and 45 down by implying into the provision a requirement that an officer should have a reasonable suspicion before he exercises the power. ${ }^{299}$ In the South African case Lawyers for Human Rights v Minister of Home Affairs ${ }^{300}$ the constitutionality of an immigration officer's statutory discretion to detain a person he believed to be an illegal immigrant was challenged. The power in s. 34(8) of the South African Immigration Act 2002 to detain 'illegal foreigners' was not constrained by any criteria. There was for example no requirement that the officer possess a reasonable suspicion that an individual was an illegal foreigner. Thus under s. 34(8) a person who was not an illegal foreigner, but who had been declared as such by an immigration officer, could be lawfully detained and deported. The High Court declared s. 34(8) to be unconstitutional. However, on appeal the Constitutional Court reversed this decision. Yacoob J concluded that if the interpretation taken by the High Court was correct, then s. 34(8) was indeed unconstitutional. However, the section could be interpreted in a constitutional manner by requiring that a reasonable suspicion be present for the discretion's lawful exercise. The adoption of such an interpretation would not unduly strain the language of the statute. However, a court might take the view that the legislation is so permissive that it is not possible to read the sections down. The protection of basic rights 'should not be dependent upon a reliance on the continuous exemplary conduct of the executive, something that is impossible to monitor or control' ${ }^{301}$ As Sopinka J observed in Little Sisters if the legislation itself lends itself to the repeated violation of Charter rights . . . the legislative scheme itself is partially responsible

297 R v Grant [2005] 3 WLR 437 at para. 56, per Laws LJ.

298 The People v Defoe (1926) 242 NY 13 at 23-4 per Cardozo J: 'The pettiest peace officer would have it in his power through overzeal or indiscretion to confer immunity upon an offender for crimes the most flagitious. A room is searched against the law, and the body of a murdered man is found. If the place of discovery may not be proved, the other circumstances may be insufficient to connect the defendant with the crime. The privacy of the home has been infringed, and the murderer goes free. Another search, once more against the law, discloses counterfeit money or the implements of forgery. The absence of a warrant means the freedom of the forger. Like instances can be multiplied'.

$299 R$ v A (No. 2) [2002] 1 AC 45.

300 CCT 18/03, 2004 (4) 5A 125(CC).

$301 R$ v Bain [1992] 1 SCR 91, at 103-104 per Cory J. 
and must be remedied' ${ }^{302}$ A declaration of incompatibility under s. 4 of the HRA is thus the only appropriate remedy.

'A mistake by the judiciary in times of terrorism', concluded Justice Barak, 'is worse than a mistake of the legislature and the executive in times of terrorism ... . the reason is that the judiciary's mistakes will remain with the democracy when the threat of terrorism passes and will be entrenched in the case law of the court as a magnet for the development of new and problematic laws'. ${ }^{303}$ The decision of the House of Lords in Gillan is one such mistake. The deferential judgment failed to give full and proper effect to a number of important Convention rights, in effect leaving the executive free to introduce broad sweeping powers of stop and search more widely. Experience shows that the 'relaxation of basic constraints on official power are rarely confined to situations of the emergency that gave rise to them' ${ }^{304}$ At the same time the judgment in Gillan weakens the normative value of legality by approving a power that may be exercised arbitrarily in a manner that denies equality of treatment. ${ }^{305}$

302 Little Sisters Book and Art Emporium v Canada (Minister of Justice) [2000] 2 SCR 1120 at para. 205, citing remarks by Dickson J, in Hunter v Southam [1984] 2 SCR 145 at 166.

303 A. Barak, The Judge in a Democracy (PUP: Princeton, 2005) 285.

304 F. A. Allen, The Habits of Legality (OUP: New York, 1996) 42.

305 Ibid. at 72. 